\title{
ASSESSMENT OF MERCURY IN THE SAVANNAH RIVER SITE ENVIRONMENT (U)
}

\author{
E.J. Kvartek \\ W.H. Cariton \\ M. Denham \\ L. Eldridge \\ M.C. Newman
}

Westinghouse Savannah River Company

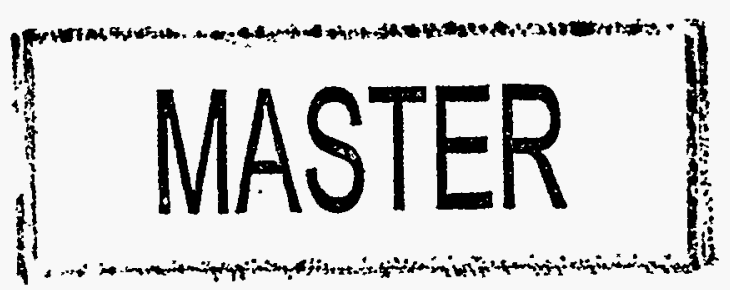

HA ATER 
This report was prepared by the Westinghouse Savannah River Company (WSRC) for the United States Department of Energy under Contract No. DE-AC09-89SR18035 and is an account of work performed under that contract. Neither the United States Department of Energy, nor WSRC, nor any of their employees make any warranty, expressed or implied, nor assume any legal liability or responsibility for the accuracy, completeness, or usefulness, of any information, apparatus, or product or process disclosed herein or represents that its use will not infringe privately owned rights. Reference herein to any specific commercial product, process, or service by trademark, name, manufacturer, or otherwise does not necessarily constitute or imply endorsement, recommendation, or favoring of the same by WSRC or by the United States Government or any agency thereof. The views and opinions of the authors expressed herein do not necessarily state or reflect those of the U.S. Government or any agency thereof.

This report has been reproduced directly from the best available copy

Available to DOE and DOE Contractors from the

Office of Scientific and Technical Information,

P..O. Box 62,

Oak Ridge TN 37831;

Prices available from

(615) 576-8401

FTS 626-8401

Available to the public from the National Technical Information Service,

U.S. Department of Commerce

5285 Port Royal Road

Springfield VA 22161

Published in cooperation with the Management Information Services Publications Group.
Editor: Henry A. Hancock, Jr.




\section{DISCLAIMER}

Portions of this document may be illegible in electronic image products. Images are produced from the best available original document. 


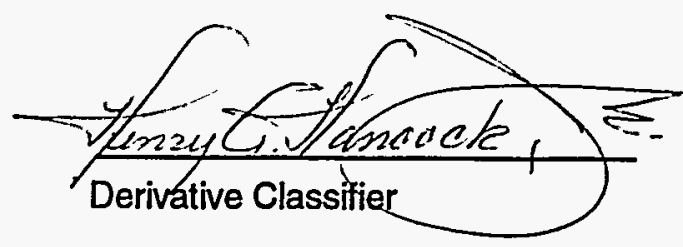

\title{
ASSESSMENT OF MERCURY IN THE SAVANNAH RIVER SITE ENVIRONMENT (U)
}

\author{
E.J. Kvartek \\ W.H. Cartton \\ M. Denham \\ L. Eldridge \\ M.C. Newman
}

Approved by:

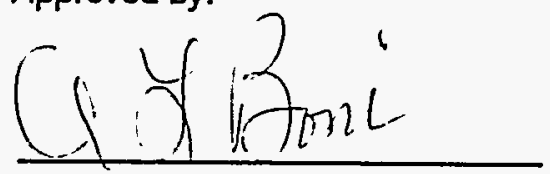

A.L. Boni

Environmental Technology Section

Savannah River Technology Center

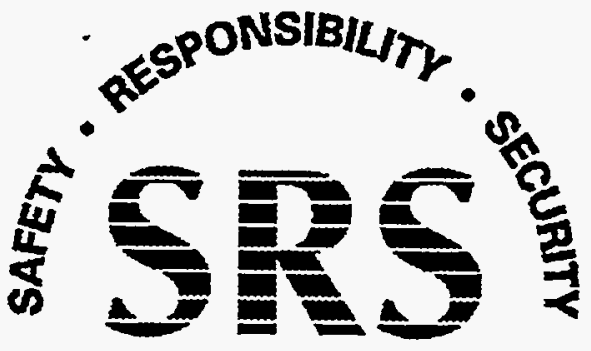




\section{CONTENTS}

Executive Summary ................................................................................... $i$

Chapter 1. Introduction .......................................................................................... 1-1

Mercury in History ....................................................................................................................... 1-3

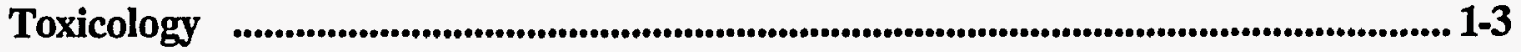

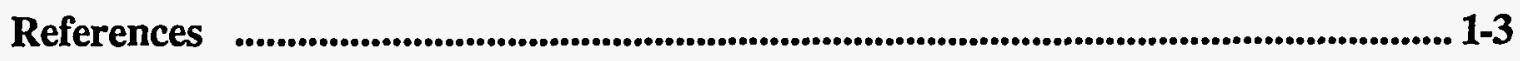

Chapter 2. Savannah River Site Operations Involving Mercury ........................ 2-1

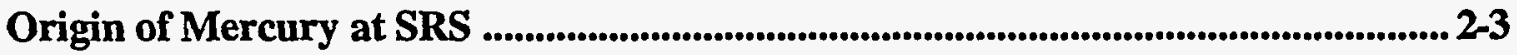

Site Operations ......................................................................................................................................2-3

Mercury in the Separation Areas as a Process Aid ..................................................................................2-4

Mercury in the Tritium Facilities Gas Handling System ...................................................................2-4

Mercury in Experimental, Laboratory, and Process Support Facilities...........................................2-5

Mercury in Waste Facilities ...........................................................................................................2-5

Underground Waste Tanks ..................................................................................................................2-5

Seepage Basins .............................................................................................................................2 2-5

Solid Waste Disposal Facility Solvent Tanks ...................................................................2-6

Solid Waste Disposal Facility .............................................................................................................2-6

Sanitary Landfill ................................................................................................................2-6

Other Waste Storage Facilities ............................................................................................2-6

Mercury in Miscellaneous Locations .......................................................................................2-6

Mercury from Naturally Occurring or Manmade Sources Not

References ............................................................................................................................................. 2-6

\section{Chapter 3. Releases and Stored Inventories of Mercury at the} Savannah River Site

\section{Releases of Mercury at SRS}

Mercury Releases from the Separation Areas ..................................................................................3-3

Mercury Releases from the Tritium Facilities .................................................................................. 3-3

Mercury Releases from Experimental, Laboratory, and Process Support Facilities .....................3-4

Mercury Releases from Waste Facilities ................................................................................34

Underground Waste Tanks .........................................................................................................3-4

Seepage Basins .......................................................................................................... 3-4

Solid Waste Disposal Facility Solvent Tanks ....................................................................3-4

Solid Waste Disposal Facility .....................................................................................................3-4

Sanitary Landfill .......................................................................................................................... 3-5

Other Waste Storage Facilities ............................................................................................. 3-5

Mercury Releases from Miscellaneous Locations ...........................................................................3-5

Releases from Naturally Occurring or Manmade Sources Not

Indigenous to the Savannah River Site .....................................................................................3-6

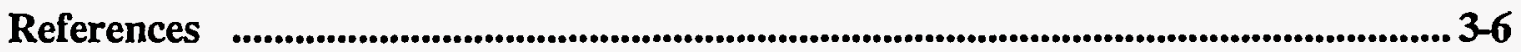




\section{Chapter 4 Mercury Concentration and Transport Mechanism}

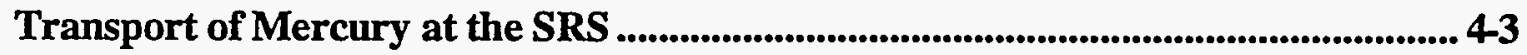

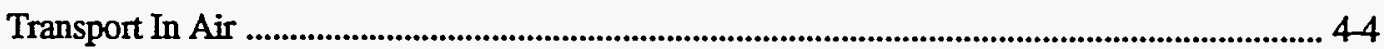

Groundwater Concentrations and Transport .................................................................................... 4-5

SRS Groundwater System ..................................................................................................... 45

Mercury in SRS Groundwater .................................................................................................. 4-7

General Separations Area Seepage Basins .................................................................. 4-8

F-Area Seepage Basins ........................................................................................................ 4-8

H-Area Seepage Basins .................................................................................................... 4-9

Solid Waste Disposal Facility ........................................................................................... 4-9

Other Measurements of Mercury at SRS ................................................................................ 4-10

References ........................................................................................................................................... 4-12

\section{Chapter 5. Environmental Research on Mercury by Savannah River Ecology}

Laboratory ....................................................................................................5-1

Overview $\quad$.

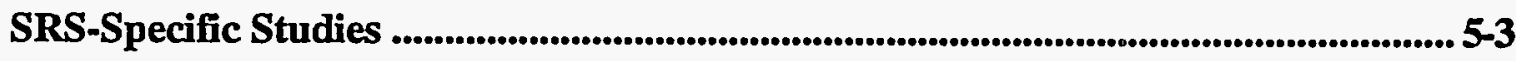

SRS-Wide Studies ............................................................................................................... 5-3

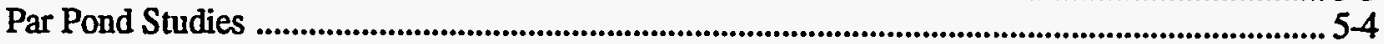

Upper Three Runs Creek Studies........................................................................................... 5-5

Basic Studies of Bioaccumulation ................................................................................... 5-6

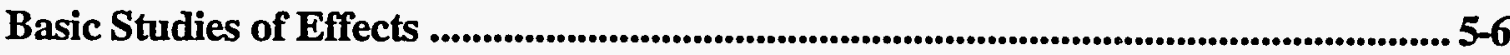

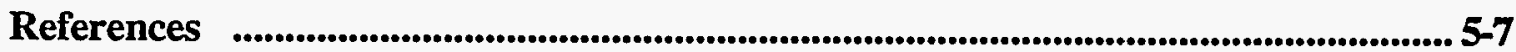

\section{Chapter 6. Assessment of Intakes/Risk from SRS Mercury}

Releases.

Assessment of the Impact of Mercury Releases at the SRS ................................. 6-3

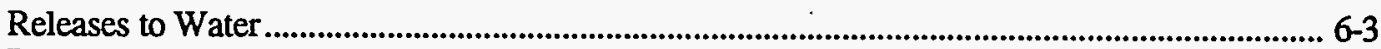

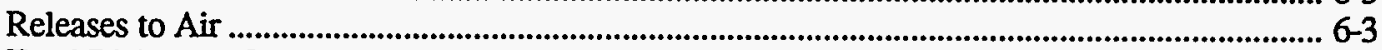

Total Risk from Oral and Inhalation Exposure ................................................................................. 6-4

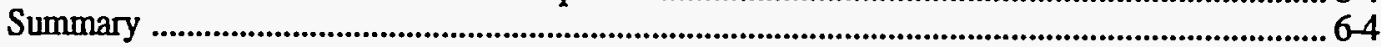

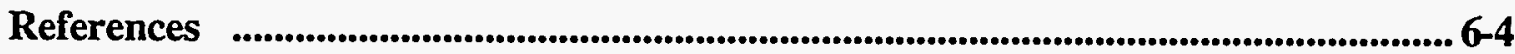




\section{Appendix A Environmental Monitoring for Mercury ........................................ A-1}

Mercury in Water Discharges ................................................................................ A-3

NPDES Sampling Locations and Frequency of Sampling for Mercury ........................................A-3

NPDES Stormwater Discharge Locations and Frequency of Sampling .........................................A-3

Surface Water Surveillance for Mercury ............................................................. A-3

Savannah River Sampling Locations ..............................................................................

Site Stream Sampling Locations .................................................................................................

Sediment Sampling for Mercury ..................................................................................... A-4

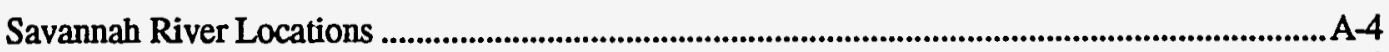

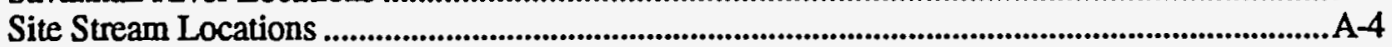

Control Sites .........................................................................................................................................

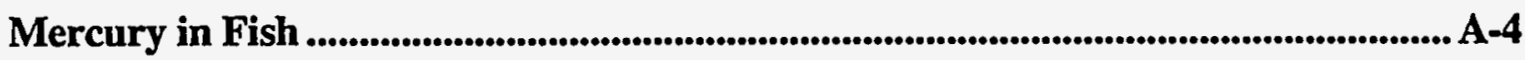

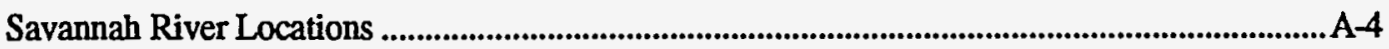

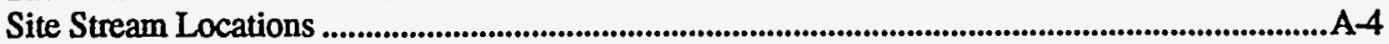

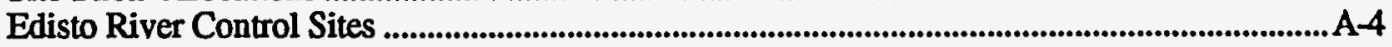




\section{List of Tables}

2-1 Mercury Use in Separation Areas (Pickett et al 1989) 2-8

2-2 Tritium Facilities Mercury Pump Inventory During Third Quarter 199.2 (Rowan 1994) .........................2-9

2-3 Facilities Storing Mercury in Calendar Year $1993 \ldots$

2-4 Wastes in the Mixed Waste Streams Inventory Report that Contain Mercury ...........................................2-10

2-5 Coal Bumed at the Savannah River Site for the Years 1980-1993..............................................................2-11

3-1 Mercury in Groundwater Samples During Calendar Year 1992 (Amett et al 1993) ..................................3-7

3-2 Mercury Use (kg) in the H-Area \& F-Area Canyon Facilities by Year...................................................3-7

3-3 Mercury Use (kg) in the Tritium Facilities ...................................................................................................3-8

3-4 Mercury Air Emissions Inventory for the Savannah River Site ..............................................................3-8

3-5 Mercury Emissions as Reported in the 1990 Savannah River Site Air Emissions Inventory for Calendar Year 1990 ...................................................................................................... 3-9

3-6 Estimated Releases of Mercury from the Combustion of Coal at the Savannah River Site for the years 1980-1993

3-7 Mercury in Par Pond \& Pond C Sediment (Amett et al 1992) ......................................................................3-10

3-8 Mercury in Fish (Amett et al 1992) ............................................................................................................10

4-1 Releases of Mercury to the Environment (U.S. Public Health Service 1989. .................................................4-3

5-1 Muscle Tissue Mercury Concentrations (ppm wet weight) for Five Waterfowl Species Captured from Par Pond from October 1977 to March 1978

5-2 Preliminary Mercury Analyses of Upper Three Runs Creek (U3R) Water.

5-3 Mercury Concentrations (ppm wet weight) Measured in Dusky Shiners from Upper Three Runs Creek. 


\section{List of Figures}

2-1 Areas Within the SRS Which May Be Sources of Mercury Releases...................................................... 2-2

2-2 Flow Chart of Mercury Use, Disposal, and Release. ............................................................................ 2-3

4-1 Schematic Representations of the Components, Transformations,

Exchanges, and Transport Pathways of Mercury...................................................................... 4-4

4-2 Geological Cross-Section Showing the Main Aquifers.......................................................................... 4-5

4-3 Stratigraphic and Hydrostratigraphic Nomenclature Used on the Savannah River Site .......................... 4-6

4-4 Updip Limits of the Confining Systems in the Coastal Plain Sediments ................................................4-7

4-5 Hydraulic Head Differences Across Confining Units Near the Cretaceous/Tertiary Boundary. .............. 4-7

46 Location Map of Waste Disposal Sites in the General Separations Area. ................................................. 4-8

47 Contours of Mercury Concentration in the Groundwater of the Water Table Aquifer near

F-Area Seepage Basins ......................................................................................................4-11

4-8 Contours of Mercury Concentration in the Groundwater of the Water Table Aquifer near

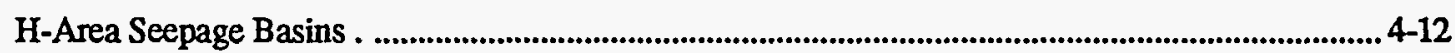




\section{Executive Summary}

Mercury has been valued by humans for several millennia. Its principal ore, cinnabar, was mined for its distinctive reddish-gold color and high density. Mercury and its salts were used as medicines and aphrodisiacs.

At SRS, mercury originated from one of the following: as a processing aid in aluminum dissolution and chloride precipitation; as part of the tritium facilities' gas handling system; from experimental, laboratory, or process support facilities; and as a waste from site operations. Mercury is also found in Par Pond and some SRS streams as the result of discharges from a mercury-cell-type chlor-alkali plant near the city of Augusta, GA. Reactor cooling water, drawn from the Savannah River, transported mercury onto the SRS.

Approximately $80,000 \mathrm{~kg}$ of mercury is contained in the high level waste tanks and $10,000 \mathrm{~kg}$ is located in the SWDF. Additional quantities are located in the various seepage basins. In 1992, 617 wells were monitored for mercury contamination, with 47 indicating contamination in excess of the 0.002-ppm EPA Primary Drinking Water Standard.

More than 20 Savannah River Ecology Laboratory (SREL) reports and publications pertinent to mercury $(\mathrm{Hg})$ have been generated during the last two decades. They are divided into three groupings: SRS-specific studies, basic studies of bioaccumulation, and basic studies of effect. Many studies have taken place at Par Pond and Upper Three Runs Creek.

Mercury has been detected in wells monitoring the groundwater beneath SRS, but not in water supply wells in excess of the Primary Drinking Water Limit of 0.002 ppm. There has been no significant release of mercury from SRS to the Savannah River. While releases to air are likely, based on process knowledge, modeling of the releases indicates concentrations that are well below the SCDHEC ambient standard. 
This page intentionally left blank. 


\section{Chapter 1. Introduction}

Mercury has been of interest to humans since prehistory, when its principal ore, cinnabar, was valued for its distinctive reddish-gold color and high density.

The principal source of mercury in the environment is the natural outgassing from the earth's crust, which accounts for $2.5 \times 10^{7}$ to $1.5 \times 10^{8} \mathrm{~kg}$ annually. This far exceeds mercury releases due to human activities, which are estimated to be about $3.0 \times 10^{6} \mathrm{~kg}$ per year 
This page intentionally left blank. 


\section{Mercury in History}

Mercury has been of interest to humans since prehistory, when its principal ore, cinnabar, was valued for its distinctive reddish-gold color and high density. Large amounts of cinnabar were transported to Rome, where it was reduced to vermilion and used in paint and cosmetics. Aristotle and Pliney both wrote about mercury. Mercury and mercury salts were used as medicines to prolong life, as aphrodisiacs, as medicinal ointments to treat skin diseases, and as a cure for syphilis (DTtri 1972).

The principal source of mercury in the environment is the natural outgassing from the earth's crust, which accounts for $2.3 \times 10^{7}$ to $1.4 \times 10^{8} \mathrm{~kg}$ annually. This far exceeds mercury releases due to human activities, which are estimated to be about $9.1 \times 10^{6} \mathrm{~kg}$ per year (Klaassen et al. 1986).

The widespread distribution of mercury was reported by the EPA (EPA 1983) which measured mercury in urban runoff in three of 28 U.S. cities, at concentrations of 0.6 to 1.2 micrograms per liter. Presumably originating from nonpoint sources, mercury contaminated the urban runoff as rainwater flushed various surfaces. The report suggested further evaluation of mercury and other heavy metals in urban runoff.

\section{Toxicology}

Mercury generally is divided into three categories based on toxicological effects: elemental, inorganic, and organic. The inhalation of elemental mercury produces a variety of symptoms: wakefulness, muscle weakness, anorexia, headache, tinnitus, hypermotility, diarrhea, liver changes, dermatitis, and fever (Lewis 1991).

Inorganic mercury affects the central nervous system, mouth, and gums. The first symptoms are excessive salivation and painful chewing. Loss of memory, insomnia, lack of confidence, vague fears and depression also may occur (Lewis 1991).
Methyl mercury is the most important form of organic mercury in terms of health effects. Most of the knowledge of methyl mercury toxicology is from epidemiologic studies of exposed populations.

Two major epidemics of methyl mercury poisoning have occurred in Japan in Minamata Bay and in Niigata. Both were caused by industrial release of methyl and other mercury compounds .

The largest recorded epidemic of methyl mercury poisoning took place in Iraq during the winter of 1971-72, resulting in the admission of over 6000 patients to hospitals and over 500 deaths. The exposure was from bread containing seed grain which had been coated with a fimgicide; methyl mercury.

\section{References}

D'Itri, F.M., 1972, The Environmental Mercury Problem, CRC Press, Cleveland, Ohio.

EPA, Results of the Nationwide Runoff Program, Volume 1-Final Report, NTIS Accession Number PB84-185552, Water Planning Division, United States Environmental Protection Agency, December, 1983.
Klaassen, C.D., M.O. Amdur, and J. Doull, 1986, Casarett and Doull's Toxicology, Third Edition, Macmillan Publishing Company, New York.

Lewis, R.J., Jr., 1991, Hazardous Chemicals Desk Reference, Second Edition, Van Nostrand Reinhold, New York. 
i

This page intentionally left blank 


\section{Mercury in History}

Mercury has been of interest to humans since prehistory, when its principal ore, cinnabar, was valued for its distinctive reddish-gold color and high density. Large amounts of cinnabar were transported to Rome, where it was reduced to vermilion and used in paint and cosmetics. Aristotle and Pliney both wrote about mercury. Mercury and mercury salts were used as medicines to prolong life, as aphrodisiacs, as medicinal ointments to treat skin diseases, and as a cure for syphilis (D'Itri 1972).
The principal source of mercury in the environment is the natural outgassing from the earth's crust, which accounts for $2.3 \times 10^{7}$ to $1.4 \times 10^{8} \mathrm{~kg}$ annually. This far exceeds mercury releases due to human activities, which are estimated to be about $9.1 \times 10^{6} \mathrm{~kg}$ per year (Klaassen et al. 1986).

\section{Toxicology}

Mercury generally is divided into three categories based on toxicological effects: elemental, inorganic, and organic. The inhalation of elemental mercury produces a variety of symptoms: wakefulness, muscle weakness, anorexia, headache, tinnitus, hypermotility, diarrhea, liver changes, dermatitis, and fever (Lewis 1991).

Inorganic mercury affects the central nervous system, mouth, and gums. The first symptoms are excessive salivation and painful chewing. Loss of memory, insomnia, lack of confidence, vague fears and depression also may occur (Lewis 1991).
Methyl mercury is the most important form of organic mercury in terms of health effects. Most of the knowledge of methyl mercury toxicology is from epidemiologic studies of exposed populations.

Two major epidemics of methyl mercury poisoning have occurred in Japan in Minamata Bay and in Niigata. Both were caused by industrial release of methyl and other mercury compounds .

The largest recorded epidemic of methyl mercury poisoning took place in Iraq during the winter of $1971-72$, resulting in the admission of over 6000 patients to hospitals and over 500 deaths. The exposure was from bread containing seed grain which had been coated with a fungicide; methyl mercury.

\section{References}

\section{D'Itri, F.M., 1972, The Environmental Mercury} Problem, CRC Press, Cleveland, Ohio.

Klaassen, C.D., M.O. Amdur, and J. Doull, 1986, Casarett and Doull's Toxicology, Third Edition, Macmillan Publishing Company, New York.
Lewis, R.J., Ir., 1991, Hazardous Chemicals Desk Reference, Second Edition, Van Nostrand Reinhold, New York. 
This page intentionally left blank 


\section{Chapter 2. The Savannah River Site Operations Involving Mercury}

This chapter gives a general overview of the locations and processes where mercury has been used at the Savannah River Site (SRS). 


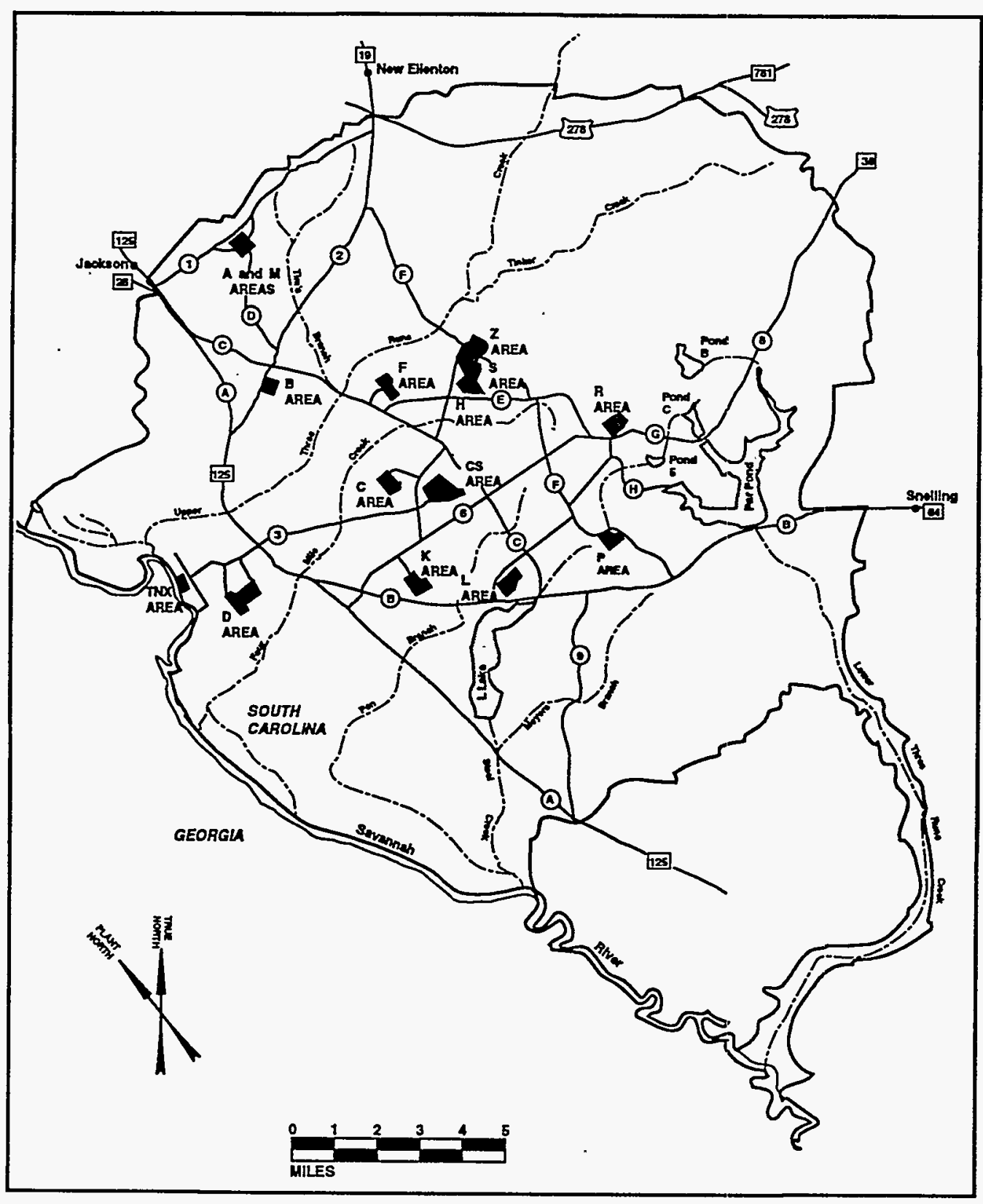

Figure 2.1 Areas Within the SRS Which May Be Sources of Mercury Releases. 


\section{Origin of Mercury at the SRS}

Mercury, unlike various radionuclides, is not produced intentionally at SRS. Where present, mercury likely originated from one of the following: as a processing aid in aluminum dissolution and chloride precipitation; as part of the tritium facilities' gas handling system; from experimental, laboratory, or process support facilities; and as a waste from site operations. In addition, the presence of mercury can be linked to naturally occurring or manmade sources not indigenous to SRS. Locations of mercury use and disposal at SRS are illustrated in Figure 2.1 and Figure 2.2.

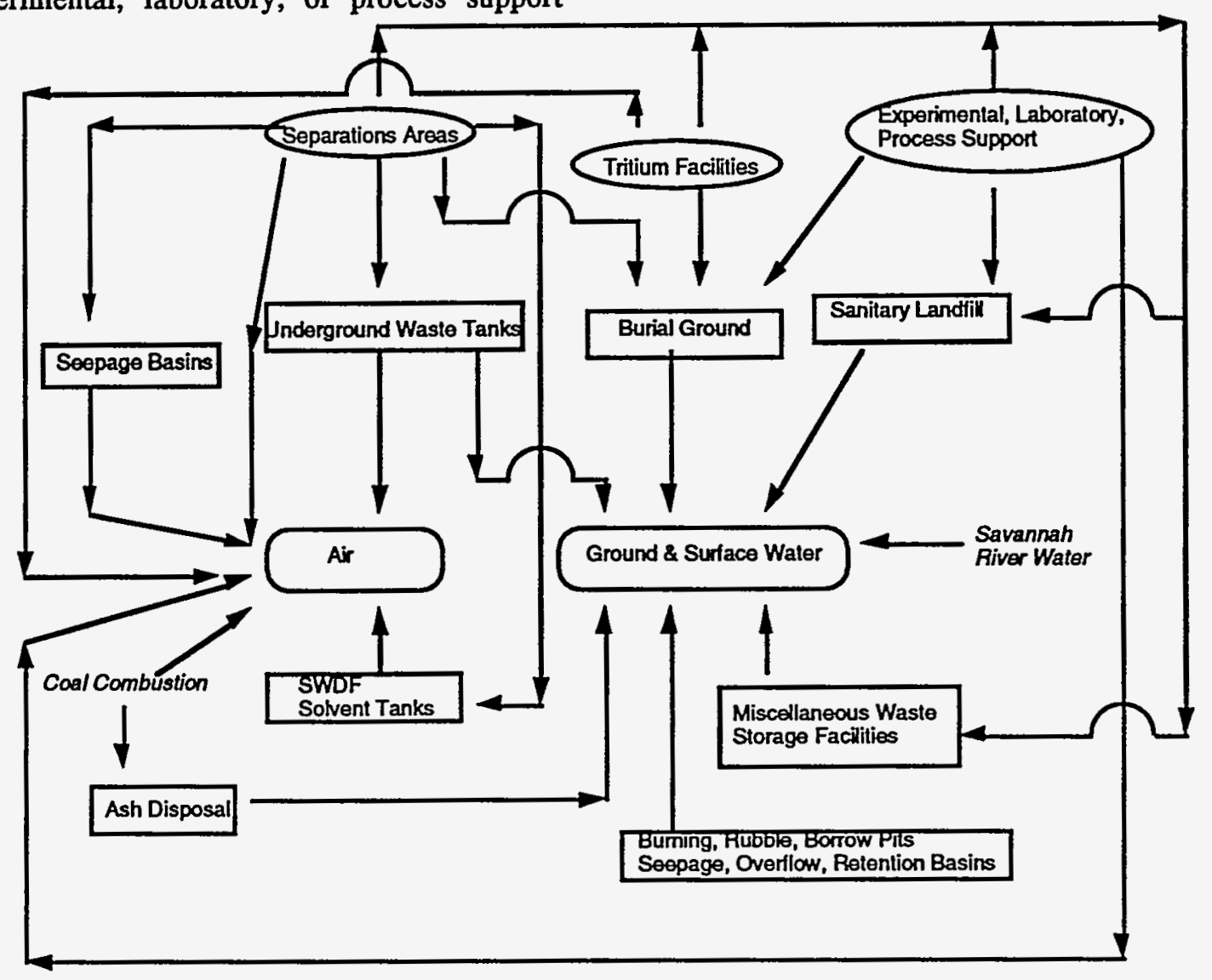

Figure 2.2. Flowchart of Mercury Use, Disposal, and Release.

\section{Site Operations}

Five production reactors have operated at SRS. The role of the reactors was to produce special nuclear materials-principally tritium and plutonium-for national defense purposes. Additional radionuclides-such as $238 \mathrm{Pu}$, a power source for certain deep-space missionsoccasionally were produced for other government and civilian purposes.

Following start-up in 1953-1955, the reactors did not operate continuously. They alternated between operating periods for production and shutdown periods for maintenance or the replacement of fuel and targets. As of 1994, four reactors were shut down and one was in a standby mode.

Two chemical separation facilities and their associated liquid waste storage facilities are located near the center of the site. The two separation areas are identified by letter designations $\mathrm{F}$ and $\mathrm{H}$. In these areas, the products of interest from reactor 
irradiation were chemically separated and purified from waste products.

Waste facilities in or adjacent to the separation facilities were designed for liquid waste handling. Depending on activity level, liquid wastes were stored in waste tanks or sent to either seepage basins or the Effluent Treatment Facility (ETF). In November 1988 the ETF became operational to treat the wastes that previously were sent to seepage basins. The seepage basins were closed in 1988 and have been decommissioned.

Radioactive solid wastes generated during SRS operations were burned in a low-level waste incinerator or buried in the Solid Waste Disposal Facility (SWDF, formerly called the Burial Ground).

\section{Mercury in the Separation Areas as a Processing Aid}

Mercury has been used as a processing aid in the separation areas, as a catalyst to increase the rate at which aluminum dissolves in nitric acid and as a precipitating agent for removing chlorides (Pickett et al. 1989). As a catalyst, mercury is necessary during dissolution of uranium-aluminum alloy reactor fuel, plutonium-aluminum targets, and scrub-alloy scrap. As a precipitating agent, mercury is necessary to remove chlorides, which otherwise would result in corrosion of stainless steel in processing equipment.

Building 221- $\mathrm{H}$ initiated the use of mercury in 1959 as part of the HM process to recover enriched uranium from spent uranium-aluminum reactor fuel (Pickett et al. 1989). The use of mercury to recover ${ }^{238} \mathrm{Pu}$ and ${ }^{237} \mathrm{~Np}$ in the $221-\mathrm{H}$ frames process followed in 1961 (Pickett et al. 1989). About 7 and $5 \mathrm{~kg}$ of mercury were added in the 221-H large and small dissolvers, respectively, for each run (Pickett et al. 1989).

Mercury initially was introduced in Building 221-F in 1965 (Pickett et al. 1989) to dissolve plutoniumaluminum targets and scrap. The use of mercury during the recovery of plutonium from Rocky Flats scrub-alloy plutonium-aluminum scrap began in 1984. About $105 \mathrm{~kg}$ of mercury was used to dissolve the aluminum and precipitate the chlorides in a typical charge.
Table 2-1 summarizes the various campaigns during which mercury has been used in the separation areas and lists the concentration of mercury used for the charge(s). Beginning in March 1985, the quantity of mercury added to the dissolvers was reduced to a concentration of $0.002 \mathrm{M}$ to minimize the amount of mixed hazardous waste (which contains both radioactive and hazardous waste) generated. To date, no suitable mercury replacement that could be implemented using existing equipment has been identified (Gray 1984).

\section{Mercury in the Tritium Facilities Gas Handling System}

Mercury has been used in the operation of various mechanical and diffusion pumps involved in the handling of tritium gas. The mercury generates a vacuum used to transfer tritium gas and evacuate process equipment (WSRC 1992a).

Various types of pumps have used mercury in the tritium facilities. All the pumps share a common feature; they have reservoirs containing circulating mercury. Depending on the location within the process, pumps typically contain 3 to $105 \mathrm{~kg}$ of mercury. Table 2-2 lists the number of pumps in the tritium facilities-and identifies the quantity of mercury in the pumps-during the third quarter of 1992.

Through 1968, all mercury drained during pump maintenance and replacement was buried as waste (Johnson 1983). One-liter polyethylene bottles served as primary burial containers. Two to three polyethylene bottles were placed in metal cans and buried in the 643-E (formerly 643-G) SWDF (Orebaugh and Hale 1976). Beginning in 1968, mercury drained from pumps was reused after oxidized mercury and metallic impurities were removed through a decanting step (Orebaugh 1984). As a result, the burial of mercury from the tritium facilities decreased. In fact, no new mercury has been added to the overall tritium facilities' inventory since 1987 (Rowan 1994).

Mercury also can be found in tritium gas distribution piping and in gold traps installed to collect trace amounts of mercury that can enter the distribution piping. 


\section{Mercury in Experimental, Laboratory, and Process Support Facilities}

Mercury's presence can be traced to many areas of SRS. Table 2-3, developed from information in the Savannah River Site Hazardous Chemicals Inventory for calendar year 1993, lists the facilities where mercury was reported as present during 1993.

Historically, mercury has been used as a chemical reagent or component of equipment in virtually every laboratory at SRS. As a laboratory standard, it was used for testing reactor moderator (process safety), for analyzing evaporator overheads (environmental releases), and for determining the concentration of feed materials (process control). A more recent use involves the addition of mercury to nonradioactive simulated waste, primarily at SRTC, TNX, and DWPF, to model the fate of mercury as part of development and testing for the DWPF process.

In laboratory devices, mercury can be found in thermometers, manometers, barometers, and test equipment. Breakage and replacement of these devices is common. In addition, some of the original process support equipment, since replaced, contained mercury. Examples include flow transmitters, switches, relays, pressure monitors, fluorescent light tubes, and batteries.

No regulations required mercury tracking prior to the Emergency Planning and Community Right-toKnow Act of 1986. Little information is readily available to describe or quantify the amount of mercury used prior to 1986, except in the separation and tritium facilities.

\section{Mercury in Waste Facilities}

\section{Underground Waste Tanks}

As a catalyst, mercury is not consumed by the processes in the separation areas. With the exception of mercury released as a vapor via the chemical separation areas' stacks, or carried along with recycled or spent processing chemicals and overheads, the mercury used in each charge remained in the dissolver solution. After the radionuclides of interest have been removed, the dissolver solution, containing the mercury, was transferred to the underground waste tanks.
In the underground waste tanks, the mercury distributed between a heavy sludge and a lighter supernate in a 9:1 ratio (Ebra and Wiley 1984). Mercury in the sludge settled to the bottom of the underground storage tanks. Although mercury is volatile and can volatize beneath the sludge, little of it actually is released. The mercury present as part of the sludge will remain in the underground waste tanks until startup of the DWPF.

\section{Seepage Basins}

To reduce the amount of material the separation areas sent to the underground waste tanks, liquids were evaporated. Overheads-which may contain mercury, depending on the phase of the processwere sent to the separation areas' seepage basins. Likewise, to maximize available tank space, waste from other sources sent to the underground storage tanks was also evaporated to reduce its volume, and these overheads may have added mercury to the separation areas' seepage basins. These seepage basins were operated until 1988 , when they were removed from service. Overheads from the separation areas now are sent to the 200-Areas ETF which is designed to effectively remove mercury.

\section{Solid Waste Disposal Facility (SWDF) Solvent Tanks}

Several tanks, known collectively as the SWDF solvent tanks, store spent canyon solvent (tributyl phosphate and n-paraffin). The spent solvent has been analyzed and contains up to $13 \mathrm{ppm}$ (weighted average of the aqueous and organic fractions) of mercury (Odum 1992).

\section{Solid Waste Disposal Facility}

Between 1956 and 1968, an estimated 10,000 kg of mercury was sent to the 643-E SWDF, primarily from the tritium facilities (WSRC, 1992b). After 1968 , the only mercury received from the tritium facilities at the 643-E SWDF was that which could not be drained from pumps and associated equipment, that retained in gold traps, and from leaks. In addition to the tritium facilities, mercury from other SRS sources (cleanup of leaks, discarded mercury-containing equipment), which originated within radiologically controlled areas was sent to the 643-E SWDF. The 643-E SWDF was filled in 1972 and replaced with the 643-7E (formerly 643-7G) SWDF. Little if any mercury is buried in the 643-7E SWDF. 


\section{Sanitary Landfill}

The Sanitary Landfill, 740-G, began receiving nonradioactive solid waste from site activities in 1974. Presumably, small quantities of mercury from items such as thermometers, switches, fluorescent light tubes, etc., could have been discarded in this facility. Since at least 1984, and perhaps earlier, no mercury was sent to the sanitary landfill.

\section{Other Waste Storage Facilities}

Wastes sometimes are contaminated with radioactive and hazardous materials. These wastes, termed mixed hazardous waste, are described in the Mixed Waste Streams Inventory Report - Phase 2. Table 2-4 describes wastes that contain both mercury and radioactive materials.

\section{Mercury in Miscellaneous Locations}

Since the startup of operations, materials used in site support facilities have been discarded in various burning, rubble, and borrow pits, as well as in seepage, overflow, and retention basins. Examples of the materials include construction rubble, fluorescent light tubes, small broken equipment, excess or contaminated (nonradioactive) chemicals, spill-cleanup materials, and maintenance wastes. Information about type(s) of material sent to these sites is, in some instances, sketchy. Many of the locations had the potential to receive mercury as a waste. The locations are described in the Federal Facility Agreement Progress Report, most recently issued as document WSRC-RP-93-1155, October 1993.

\section{Mercury from Naturally Occurring or Manmade Sources Not Indigenous to the Savannah River Site}

Some of the mercury detectable across the site originated not only from SRS releases, but from natural and offsite sources. Two such sources, incidental to the site's original mission, are the combustion of coal and the use of water from the Savannah River. Coal contains mercury, virtually all of which is released as a vapor, when coal is burned. Coal continues to be used at SRS. Coalfueled boilers are used to generate steam to heat buildings, operate process equipment, and produce electricity. A summary of the coal consumed since 1980 is described in Table 2-5.

Mercury can be found in Savannah River sediment and water upstream of SRS as a result of discharges from a mercury-cell-type chlor-alkali plant near the city of Augusta, GA (Georgia Water Quality Board 1971). Reduced now to less than $0.11 \mathrm{~kg}$ per day, this operation previously discharged up to $5 \mathrm{~kg}$ of mercury per day into the Savannah River. Savannah River water was used as the noncontact coolant in the reactor areas. During the history of site operations, mercury has collected in Par Pond sediments and can be found in the surface waters and fish in some SRS areas.

\section{References}

Ebra, M.A., and J.R. Wiley, 1984, Mercury Removal and Recycle From 200-Areas Waste Streams, DPST-84-487, Revision \#2, E.I. du Pont de Nemours \& Co., Aiken, SC.

Georgia Water Quality Board, 1971, Mercury Pollution Investigation in Georgia 1970-1971, Atlanta, GA.

Gray, J.H., 1984 Develop an Alternative to the Use of Mercury in $H$ Canyon, DPST-84-250, E.I. du Pont de Nemours \& Co., Aiken, SC.

Johnson, D.R., 1983, Mercury Inventory Record for Tritium Facilities, Tritium facilities Sep Tech Memo No. 438, E.I. du Pont de Nemours \& Co., Aiken, SC.
Odum, J.V., 1992, Burial Ground Solvent Tanks (U), ESH-FSG-920242 Westinghouse Savannah River Company, Aiken, SC.

Orebaugh, E.G., 1984, Recommendations for the Processing of Contaminated Mercury From Tritium Facilities Final Report - RTA 8-T, DPST84-880, E.I. du Pont de Nemours \& Co., Aiken, SC.

Orebaugh, E.G., and W.H. Hale, Jr., 1976, Dispersion Study of Buried Elemental Mercury, DP-1401, E.I. du Pont de Nemours \& Co., Aiken, SC. 
Pickett, C.E., T.G. Campbell, and W.E. Harris, 1989, Mercury Requirement for Separation Processes, OPS-STH-890145, Westinghouse Savannah River Company, Aiken, SC.

Rowan, P.J., Jr., 1994, Personal Communication to E.J. Kvartek, 6/9/94.
WSRC, 1992a, Tritium Pumps Which Once Contained Mercury Meet the RCRA Definition of "Empty Container" (U), WSRC-RP-92-376, Westinghouse Savannah River Company, Aiken, SC.

WSRC, 1992b, RFI-RI Work Plan Burial Ground Complex, WSRC-RP-90-1140, Rev. 1, Westinghouse Savannah River Company, Aiken, SC. 
Table 2-1. Mercury Use in Separation Areas (Pickett et al. 1989)

\begin{tabular}{llll}
$221-H$ & Fuel/Target & Hg Conc. in \\
Campaigns & Dissolved & Date(s) & \begin{tabular}{c} 
Dissolver (M) \\
\hline HM
\end{tabular} \\
Mark VI & $5 / 59-2 / 60$ & 0.0055 \\
Frames Process & Mark VI-J & $3 / 60-10 / 63$ & 0.021 \\
HPI-1 & Np-Al 238Pu & $3 / 61-$ Present & 0.004 \\
HPI-2 & Pu-Al & $6 / 61-7 / 61$ & 0.04 \\
HM & Pu-Al & $11 / 61-12 / 61$ & 0.04 \\
& Mark VI-B & $11 / 63-9 / 66$ & 0.019 \\
& Mark VI-S & $11 / 63-8 / 65$ & 0.019 \\
& Mark VI-C & $3 / 65-5 / 66$ & 0.019 \\
& Mark VI-F & $7 / 65-7 / 66$ & 0.02 \\
& Mark VI-JS & $10 / 66-4 / 67$ & 0.02 \\
Curium II & Mark VI-CS & $12 / 66-3 / 67$ & 0.02 \\
HM & Mark XII & $.4 / 67-12 / 67$ & 0.02 \\
& Mark VI-PS & $8 / 67$ & 0.02 \\
& Mark VI-E & $1 / 68-11 / 68$ & 0.01 \\
& Mark XII-A & $12 / 68-8 / 69$ & 0.01 \\
& Mark 14 & $4 / 69-8 / 73$ & 0.005 \\
& Mark 18 & $3 / 70-7 / 71$ & 0.0025 \\
& Mark 16 & $4 / 71-8 / 78$ & 0.013 \\
& Mark 22 & $2 / 76-3 / 85$ & 0.0125 \\
& Mark 16B & $9 / 78-3 / 85$ & 0.0125 \\
\hline
\end{tabular}

\begin{tabular}{lllc}
$\begin{array}{lll}\text { 221-F } \\
\text { Campaigns }\end{array}$ & $\begin{array}{l}\text { Fuel/Target } \\
\text { Dissolved }\end{array}$ & Date(s) & $\begin{array}{c}\text { Hg Conc. in } \\
\text { Dissolver (M) }\end{array}$ \\
\hline Curium I & Pu-Al & $6 / 65-7 / 65$ & 0.016 \\
HPI-20 & Mark VI-P & $8 / 65$ & 0.016 \\
HPI-40 & Mark VI-P & $5 / 68-6 / 68$ & 0.016 \\
Pu-Al Ingot & Pu-Al & $9 / 68$ & 0.02 \\
HPI-241 & Mark 40 & $5 / 70-6 / 70$ & 0.02 \\
Pu-242 & Mark 40 & $2 / 71$ & 0.02 \\
Mk 40 Burner 1 & Mark 40 & $7 / 71$ & 0.012 \\
Mk 40 Bumer 2 & Mark 40 & $9 / 72$ & 0.012 \\
Mk 40 Bumer 3 & Mark 40 & $3 / 73-4 / 73$ & 0.012 \\
HPI-21 & Pu-Al Slugs & $1 / 74-2 / 74$ & 0.012 \\
& Phoenix Fuel & $1 / 74-2 / 74$ & 0.012 \\
Mk 41 & Mark 40 & $1 / 74-2 / 74$ & 0.012 \\
EBR-1 & Mark 41 & $10 / 78$ & 0.012 \\
SEFOR & EBR Fuel & $11 / 83$ & 0.012 \\
RFSA & SEFOR Fuel & $7 / 84-12 / 84$ & 0.006 \\
Chloride Removal from ScrubAlloy & Rocky Flats Scrub Alloy & $5 / 84-$ Present & 0.006 \\
\hline
\end{tabular}


Table 2-2. Tritium Facilities Mercury Pump Inventory During Third Quarter 1992 (Rowan 1994)

\begin{tabular}{lcc} 
Building & $\begin{array}{c}\text { Mercury Capacity } \\
(\mathrm{kg})\end{array}$ & Number of Pumps in Inventory \\
\hline $232-\mathrm{H}$ & $2.7 \times 10^{0}$ & 6 \\
$232-\mathrm{H}$ & $1.4 \times 10^{1}$ & 6 \\
$232-\mathrm{H}$ & $1.6 \times 10^{1}$ & 2 \\
$232-\mathrm{H}$ & $2.7 \times 10^{1}$ & 4 \\
$232-\mathrm{H}$ & $5.4 \times 10^{1}$ & 2 \\
$232-\mathrm{H}$ & $1.0 \times 10^{2}$ & 2 \\
$234-\mathrm{H}$ & $2.7 \times 10^{1}$ & 6 \\
\hline
\end{tabular}

Table 2-3. Facilities Storing Mercury in Calendar Year $1993^{\text {(a) }}$

\begin{tabular}{llcc} 
Location & Type of Facility & Maximum Amount $(\mathrm{kg})$ & Average Amount $(\mathrm{kg})$ \\
\hline $305-\mathrm{A}$ & Research & $3.2 \times 10^{0}$ & $3.2 \times 10^{0}$ \\
$736-\mathrm{A}$ & Calibration & $5.5 \times 10^{0}$ & $5.5 \times 10^{0}$ \\
$773-\mathrm{A}$ & Research & $4.3 \times 10^{2}$ & $6.9 \times 10^{1}$ \\
$786-\mathrm{A}$ & Support & $<4.5 \times 10^{-1}$ & $<4.0 \times 10^{-1}$ \\
$772-\mathrm{D}$ & Process Control & $6.4 \times 10^{0}$ &. \\
$249-\mathrm{F}$ & Environmental & $<4.5 \times 10^{-1}$ & $5.9 \times 10^{0}$ \\
$772-\mathrm{F}$ & Process Control & $5.0 \times 10^{1}$ & $<4.5 \times 10^{-1}$ \\
$760-5 \mathrm{G}$ & Forest Service & $4.5 \times 10^{-1}$ & $5.0 \times 10^{1}$ \\
$221-\mathrm{H}$ & Production & $4.9 \times 10^{3}$ & $4.5 \times 10^{-1}$ \\
$232-\mathrm{H}$ & Production & $8.6 \times 10^{2}$ & $4.9 \times 10^{3}$ \\
$322-\mathrm{M}$ & Process Control & $1.4 \times 10^{0}$ & $8.6 \times 10^{2}$ \\
\hline
\end{tabular}

(a) Compounds and products containing trace amounts of mercury-e.g., batteries and environmental standards-are not included. 
Table 2-4. Wastes in the Mixed Waste Streams Inventory Report that Contain Mercury

\begin{tabular}{|c|c|c|c|c|}
\hline Source Identifier & Waste Description & $\begin{array}{l}\text { Storage } \\
\text { Location }\end{array}$ & $\begin{array}{l}\text { Quantity of } \\
\text { Material(kg) }\end{array}$ & $\begin{array}{c}\text { Amount of } \mathrm{Hg} \\
(\mathrm{kg})\end{array}$ \\
\hline SR-W003 & Routine job waste & $645-2 \mathrm{~N}$ & $1.8 \times 10^{3}$ & Present ${ }^{(\mathbf{a})}$ \\
\hline SR-W007 & Analytical waste & $776-2 A$ & $7.1 \times 10^{4}$ & $7.1 \times 10^{-3}$ \\
\hline SR-W008 & Analytical waste & $776-2 A$ & $7.7 \times 10^{4}$ & $5.9 \times 10^{-3}$ \\
\hline SR-W012 & $\begin{array}{l}\text { Toxic chemical cleanup } \\
\text { material }\end{array}$ & $645-2 \mathrm{~N}$ & $1.1 \times 10^{2}$ & Present \\
\hline SR-W014 & Hg with impurities & $232 / 4-\mathrm{H}$ & $2.5 \times 10^{3}$ & $2.5 \times 10^{3}$ \\
\hline SR-W015 & Process equipment & $\begin{array}{c}645-2 \mathrm{~N} \\
643-29 \mathrm{~N} \\
232-\mathrm{H}\end{array}$ & $6.1 \times 10^{3}$ & Present \\
\hline SR-W016 & Process waste & 241-F & $8.1 \times 10^{7}$ & Present \\
\hline SR-W017 & Process waste & $241-\mathrm{H}$ & $7.2 \times 10^{4} \mathrm{~m}^{3(\mathrm{~b})}$ & Present \\
\hline SR-W024 & Gold traps & $643-29 \mathrm{E}$ & $1.3 \times 10^{3}$ & $<4.5 \times 10^{-3}$ \\
\hline SR-W025 & Routine job waste & TRU pads & $6.4 \times 10^{5}$ & Present \\
\hline SR-W026 & Routine job waste & TRU pads & $1.5 \times 10^{4}$ & Present \\
\hline SR-W027 & Routine job waste & TRU pads & $1.1 \times 10^{6}$ & Present \\
\hline SR-W032 & Analytical waste & $645-2 N$ & $9.7 \times 10^{3}$ & $1.4 \times 10^{-2}$ \\
\hline SR-W033 & Routine job waste & TRU pads & $1.8 \times 10^{3}$ & Present \\
\hline SR-W036 & Tritiated waste oil & $232 / 4-\mathrm{H}$ & $1.1 \times 10^{4}$ & Present \\
\hline SR-W041 & $\begin{array}{l}\text { Equipment, metal, \& acid } \\
\text { waste }\end{array}$ & $645-2 N$ & $1.3 \times 10^{1}$ & Present \\
\hline SR-W042 & $\begin{array}{l}\text { Paints, paint chips, \& paint } \\
\text { solvents }\end{array}$ & $645-2 N$ & $9.4 \times 10^{2}$ & $4.5 \times 10^{-3}$ \\
\hline SR-W044 & Spent solvent tanks & $643-7 E$ & $1.0 \times 10^{3}$ & $1.4 \times 10^{-2}$ \\
\hline SR-W045 & Spent solvent tanks & $643-7 E$ & $8.5 \times 10^{4}$ & $1.1 \times 10^{0}$ \\
\hline SR-W048 & Soil \& debris & $645-2 \mathrm{~N}$ & $1.8 \times 10^{4}$ & Present \\
\hline SR-W049 & Sludge & $645-2 \mathrm{~N}$ & $1.2 \times 10^{3}$ & $1.7 \times 10^{-2}$ \\
\hline SR-W053 & Ash for Pu recovery & 235-F & $\begin{array}{l}3.1 \times 10^{1} \\
0.5 \times 10^{-2}\end{array}$ & Present \\
\hline SR-W058 & Lab waste & 773-A & $9.5 \times 10^{-2}$ & Present \\
\hline
\end{tabular}


Table 2-5. Coal Burned at the Savannah River Site for the Years 1980-1993

\begin{tabular}{cc} 
Year & Coal (kg) \\
\hline 1980 & $4.0 \times 10^{8}$ \\
1981 & $4.3 \times 10^{8}$ \\
1982 & $3.9 \times 10^{8}$ \\
1983 & $4.2 \times 10^{8}$ \\
1984 & $4.1 \times 10^{8}$ \\
1985 & $4.1 \times 10^{8}$ \\
1986 & $4.0 \times 10^{8}$ \\
1987 & $4.1 \times 10^{8}$ \\
1988 & $3.4 \times 10^{8}$ \\
1989 & $2.1 \times 10^{8}$ \\
1990 & $2.2 \times 10^{8}$ \\
1991 & $1.8 \times 10^{8}$ \\
1992 & $2.2 \times 10^{8}$ \\
1993 & $2.0 \times 10^{8}$ \\
\hline
\end{tabular}




\section{Chapter 3. Releases and Stored Inventories of Mercury at Savannah River Site}

By far, the separation and tritium facilities account for the greatest use of mercury and have the greatest potential for release. Because of mercury's critical role in these facilities, as well as its economic value, information on historical use is available, although incomplete. Mercury's use in other facilities can be inferred only from process knowledge and internal memoranda in site records.

SRS Groundwater is monitored by the Groundwater Monitoring Group of the Environmental Protection Department's Environmental Monitoring Section. More than 1,600 monitoring wells are installed at various locations, based on the potential for contaminants to enter the groundwater under the site. In 1992, 617 wells were monitored for mercury contamination, with 47 indicating contamination in excess of the 0.002 ppm Primary Drinking Water Standard. Table 3.1 summarizes the locations where mercury was identified as part of the 1992 groundwater sampling program. 
This page intentionally left blank. 
Releases of Mercury at the SRS

\section{Mercury Releases from the Separation Areas}

Table 3.2, developed using information available in Essential Materials Transaction Reports for the Separations Department, provides a summary of the amounts of mercury used in the chemical separation processes. Mercury discharges were primarily to the underground storage tanks, to surface or groundwaters through seepage basins prior to the startup of the 200-Areas ETF, or to the air through process stacks. The majority is contained in the underground waste tanks. In 1989, it was estimated that the mercury inventory in these tanks was in the range of $7.3 \times 10^{4}$ to $9.1 \times 10^{4} \mathrm{~kg}$ (Cobb 1989).

Mercury was discharged to the separation area seepage basins as a constituent of liquid releases from the chemical separation processes, prior to basin closure in 1988. These discharges originated from the use of mercury in the chemical separation process and, to some extent, from its presence as an impurity in sodium hydroxide used in the process (Horton 1974a). For example, during the period January through November 1985, while Rocky Flats Scrub Alloy/SEFOR fuel (RFSA/SEFOR) processing occurred in $F$ Area, mercury concentrations at the trebler leading to the F-Area seepage basin ranged between 20 and $191 \mathrm{ppb}$ (Holcomb, 1986). In 1973, it was estimated that 22 and $7.3 \mathrm{~kg}$ of mercury were discharged to the $\mathrm{H}$ and F-Area seepage basins, respectively. In 1971, $28 \mathrm{~kg}$ and $24 \mathrm{~kg}$ of mercury were discharged to the $\mathrm{H}$ - and F-Area seepage basins, respectively. The 1971 figure for F-Area probably represents a higher-than-normal amount because of an inadvertent loss of mercuric nitrate from 221-F. As an impurity in sodium hydroxide (at $1.5 \mathrm{ppm}$ ), it was estimated that in January 1971 mercury was discharged to the H-Area seepage basin at $9.0 \mathrm{x}$ $10^{-3} \mathrm{~kg}$ per day and to the F-Area Seepage basin at $4.5 \times 10^{-3} \mathrm{~kg}$ per day. As a result, through the early $1970 \mathrm{~s}, 1,600 \mathrm{~kg}$ of mercury had been released into the $\mathrm{H}$-Area seepage basins and $380 \mathrm{~kg}$ of mercury had been released to the F-Area seepage basins (Horton 1974a).

Mercury air emissions from the chemical separation processes were through the $292-\mathrm{H}$ and $292-F$ stacks. In 1988 , release of mercury from 221- $\mathrm{H}$ was estimated at $2.7 \mathrm{~kg}$ per year, with a maximum theoretical discharge of $4.8 \mathrm{~kg}$ per year
(Reinig, 1989). These estimates reflected the reduction in the concentration of mercury used for aluminum dissolution and were significantly lower than earlier estimates. Estimates of mercury released before the reduction of mercury in the dissolution process were $29 \mathrm{~kg}$ per year, with a maximum theoretical discharge of $47 \mathrm{~kg}$ per year (Reinig, 1989). Estimates were not reported for 221-F, but, on average, should be significantly less.

\section{Mercury Releases from the Tritium Facilities}

Table 3.3, developed using information available in Essential Materials Transaction Reports for the Separations Department and various memoranda, provides a summary of the mercury used in the tritium facilities. Mercury discharges were primarily to the 643-E SWDF or, to a much smaller extent, to the air through process stacks.

In 1989, the inventory of mercury in the tritium facilities was reported as follows (Schmitz 1989).

Contaminated mercury in storage

Mercury in pumps

$2,200 \mathrm{~kg}$

Fresh mercury in storage

$860 \mathrm{~kg}$

Mercury in other sources

$110 \mathrm{~kg}$

$140 \mathrm{~kg}$.

Prior to implementing the recycling of mercury drained from pumps in 1968, the tritium facilities disposed of an estimated $1.0 \times 10^{4} \mathrm{~kg}$ of mercury in the 643E SWDF (WSRC 1992). With the emphasis on mercury recycling, disposal in the burial grounds was significantly reduced.

Gold traps, each of which can contain 3 to $6 \mathrm{~g}$ of mercury (Tom 1984), and removed piping, are not a significant source of mercury in the tritium facilities. As an example, in 1984 Tritium Operations planned to remove and discard approximately 15 gold traps. In 1985, 12 gold traps required removal. Between 1985 and 1990, it was predicted that only three to 10 traps would be removed each year. The methods in which the gold traps were designed and buried, as well as how tightly mercury amalgamates with gold, indicate that little of the mercury will enter the environment in the near future (Roberts 1985).

Release of mercury from the tritium facilities was not monitored routinely. Engineering calculations in 1988 estimated that stack emissions from the 
tritium facilities were less than $0.23 \mathrm{~kg}$ of mercury per year (Reinig, 1989).

\section{Mercury Releases from Experimental, Laboratory, and Process Support Facilities}

Releases from experimental, laboratory, and process support facilities are, where monitored or estimated, extremely low. Mercury from these facilities was discharged primarily to the air or to permitted surface water outfalls.

The 1990 SRS Air Emissions Inventory lists 98 emission points for mercury. In addition to the processing facilities already described, other emission points include tanks, stacks, diesel generators, coal boilers, laboratory stacks, fugitive emissions, and an incinerator. The points are grouped into one of six locations based on the type of emission. Tables 3.4 and 3.5 summarize the source descriptions and source locations reported.

As described in footnote (a) of Table 3.4, previously unrecognized potential emission sources of mercury are being inventoried. For example, an operation in building 774-A that was studying the corrosive effects of mercury on the DWPF process has calculated mercury emissions to air of $0.43 \mathrm{~kg}$ per year (with a worst case estimate of $5.3 \mathrm{~kg}$ per year) and liquid emissions of $1.3 \mathrm{~kg}$ per year on average (Eissenberg 1984).

\section{Mercury Releases from Waste Facilities}

\section{Underground Waste Tanks}

It was estimated that the underground radioactive waste tanks contain $7.3 \times 10^{4}$ to $9.1 \times 10^{4} \mathrm{~kg}$ of mercury, primarily from the chemical separations processes (Cobb 1989). From the information available, it is reasonable to expect that the majority of mercury that was placed in the tanks is still present. The only reduction would be from air emissions, from losses with overheads at the evaporators, and from tank leaks.

By design, the underground waste tanks are continuously exhausted to prevent the buildup of flammable gases. This exhaust can release mercury present in the vapor space above the waste. Engineering calculations in 1988 estimated that mercury emissions from the underground waste tanks were less than $0.23 \mathrm{~kg}$ per year (Reinig 1989).

During waste evaporation, mercury is also collected at the F- and H-Area evaporators. Documentation is not available, but technical personnel associated with Waste Management Operations indicated that during normal operation one bottle of mercury (approximately $32 \mathrm{~kg}$ ) is recovered each month in H-Area, while one bottle of mercury is recovered each year in F-Area.

One of 45 wells monitoring underground waste tank operations indicates of mercury at $0.0026 \mathrm{ppm}$ (Table 3.1). This exceeds the Drinking Water Standard of $0.002 \mathrm{ppm}$ and indicates that mercury may be leaking from the underground waste tanks.

\section{Seepage Basins}

As described in the separation areas section, the chemical separation processes released an estimated $2.0 \times 10^{3} \mathrm{~kg}$ of mercury into the seepage basins through the early 1970s (Horton 1974a). Additional mercury was added before the seepage basins were removed from service in 1988. Although the seepage basins were intended to retain the mercury within sediments, well samples indicate mercury in the groundwater.

Fifteen of 108 wells associated with H-Area seepage basins, and one of 67 wells associated with F-Area seepage basins revealed maximum mercury concentrations of 0.0079 and $0.012 \mathrm{ppm}$, respectively (Table 3.1). These values are greater than the Drinking Water Standard, $0.002 \mathrm{ppm}$, and indicate that mercury is migrating through the soil below the seepage basins.

Mercury also is identified as a possible contaminant in the soil adjacent to the buried lines that transport liquids to the seepage basins.

\section{Solid Waste Disposal Facility Solvent Tanks}

There is no indication that any releases are occurring from the solvent tanks. A relatively small source term, a small overall liquid inventory, and periodic leak checks indicate that releases are not anticipated.

\section{Solid Waste Disposal Facility}

It is estimated that $1.0 \times 10^{4} \mathrm{~kg}$ of mercury has been buried in the 643-E SWDF (WSRC 1992). Mercury from any operation involving radioactive 
contamination was deposited in the 643-E SWDF, but the majority originated from the tritium facilities. Releases of mercury from the SWDF would be primarily to the groundwater.

Soil samples collected along the southern perimeter fence of the SWDF had mercury concentrations ranging from $<0.0005$ to $0.04 \mathrm{ppm}$ of mercury. Samples along Road $E$ range from $<0.0005$ to $0.018 \mathrm{ppm}$. For comparison, background mercury concentrations in soils similar to those in the SWDF ranged from 0.002 to $0.014 \mathrm{ppm}$ (WSRC 1992).

Six of 82 wells associated with the 643-E and 64328E SWDF had mercury values greater than the Drinking Water Standard, $0.002 \mathrm{ppm}$. The maximum concentration of mercury reported in the 1992 Environmental Monitoring Report was 0.004 ppm (Table 3-1). This indicates that mercury may have leaked from storage containers.

\section{Sanitary Landfill}

While mercury disposal in the sanitary landfill was controlled after 1984, and perhaps earlier, it is reasonable to assume that a small amount of mercury was discarded in the landfill; however, no estimate of the amount is available.

In 1992, one of 42 wells associated with the sanitary landfill revealed mercury at $0.0029 \mathrm{ppm}$, which is greater than the Drinking Water Standard, $0.002 \mathrm{ppm}$ (Table 3-1). This result indicates that mercury may have been disposed in, and subsequently released from, the sanitary landfill.

\section{Other Waste Storage Facilities}

Mixed hazardous wastes containing mercury are being stored in other facilities, in some cases pending development of a means for disposal. Releases of mercury from these wastes are not likely. Even if a leak occurred, with the exception of SR-W014 (mercury waste from the tritium facilities), the releases should not be significant.

\section{Mercury Releases from Miscellaneous Locations}

Groundwater in other SRS locations has mercury concentrations in excess of the Drinking Water Standard. These are listed in Table 3-1. In addition to these locations, evaluation of disposal sites that were incidental to SRS's original mission has identified several sites with mercury contamination in excess of natural levels. As sampling is conducted, mercury may be found in groundwater at these sites.

Mercury has been identified as a contaminant in the following units described in the Federal Facility Agreement Progress Report (WSRC 1993).

- D-Area Oil Seepage Basin (631-G) - Operated from 1952 to 1975; mercury has been found above detection limits.

- Old TNX Seepage Basin (904-076G) - Operated from 1954 to 1980; mercury is listed as having been released into this unit.

- Gunsite 218 Rubble Pile (631-23G) - Operated from the mid 1950s to the early 1960 s; mercury has been detected during soil plug and soil gas surveys.

- Central Shops Sludge Lagoon (080-24G) Operated from the early 1950s until 1986; elevated concentrations of mercury have been reported in soil samples.

- TNX Groundwater - Encompassing a 10 acre area, one-quarter mile east of the Savannah River in the southwestern portion of the SRS; mercury concentration is elevated in one well out of 50 . The mercury does not appear to be migrating.

- Par Pond - A 2,640-acre reservoir near the eastern edge of SRS; mercury in water and sediment is identified as a constituent of concern. In addition, elevated mercury levels are measured routinely in fish collected from Par Pond for environmental studies.

The following units have a potential for mercury contamination; however, no contamination has been confirmed to date.

- A-Area Burning/Rubble Pits (731-A, -1A, -2A) - Operated from 1951 to 1983; mercury in groundwater is identified as a constituent of concern.

- Burma Road Rubble Pit (231-4F) - Operated from 1973 to 1983; mercury is identified as a constituent of concern.

- D-Area Burning/Rubble Pits (431-D, -1D) Operated from 1951 to 1973 ; mercury in soil is identified as a constituent of concern.

- F-Area Burning/Rubble Pits (231-F, -1F, -2F) Operated from 1951 to 1973; mercury in soil is identified as a constituent of concern.

- Ford Building Seepage Basin (904-91G) Operated from 1964 to 1984; mercury in soil has been identified as a constituent of concern. One estimate, for purposes of performing a risk assessment, placed the amount of mercury in the basin at $0.18 \mathrm{~kg}$. 
- SRTC Seepage Basins - (904-51G1, -53G2, $-54 G,-55 G)$ - Operated from 1954 to 1982 ; mercury is identified as a constituent of concern.

- Central Shops Burning/Rubble Pit (631-5G) Operated from 1951 to 1978 ; mercury is listed as a potential waste constituent in soil.

\section{Releases from Naturally Occurring or Manmade Sources Not Indigenous to the Savannah River Site}

Mercury emissions from the burning of coal at the SRS have not been measured; however, estimates can be made. A 1974 report, using a value for mercury in coal of $1 \mathrm{ppm}$, and a coal consumption

\section{References}

Amett, M.W., L.K. Karapatakis, A.R. Mamatey, and J.L. Todd, 1992, Savannah River Site Environmental Report for 1991, WSRC-TR-92186, Westinghouse Savannah River Company, Aiken SC.

Arnett, M.W., L.K. Karapatakis, and A.R. Mamatey, 1993, Savannah River Site Environmental Report For 1992, WSRC-TR-93075, Westinghouse Savannah River Company, Aiken SC.

Cobb, E.L., 1989, Eliminating Mercury From the Waste Stream (U), WSRC-RP-89-1232, Rev. 1, Westinghouse Savannah River Company, Aiken SC.

Eissenberg, S.E., 1984, Mercury Emissions From WSTD Glass Lab, DPST-84-413, E.I. du Pont de Nemours \& Co., Aiken, SC.

Holcomb, H.P., 1986, Mercury in 50\% Nitric Acid Recovered in F-Canyon, DPSPU-86-272-50, E.I. du Pont de Nemours \& Co., Aiken SC.

Horton, J.H., 1973, Mercury in the 643-G Burial Ground, DPST-73-480, E.I. du Pont de Nemours \& Co., Aiken, SC.

Horton, J.H., 1974a, Mercury in the Separations Areas Seepage Basins, DPST-74-231, E.I. du Pont de Nemours \& Co., Aiken, SC.

Horton, J.H., 1974b, SRL-SRP Mercury Monitoring Program, DPST-74-389, E.I. du Pont de Nemours \& Co., Aiken, SC. rate of $6.0 \times 10^{8} \mathrm{~kg}$ per year, estimated releases of $6.0 \times 10^{2} \mathrm{~kg}$ of nercury from site powerhouses (Horton 1974b). Using a vendor reported concentration of $0.12 \mathrm{ppm}$ of mercury in coal. Table 3.6 summarizes the annual amount of mercury emitted from the SRS during the years 1980-1983 assuming that all mercury in the coal was volatized.

Surface waters, sediment, and fish at the site contain levels of mercury similar to concentrations found in some of the surrounding areas. Mercury levels in Par Pond sediments are listed in Table 3.7, while mercury levels in fish collected from SRS and surrounding surface waters are listed in Table 3.8. For more information, see Chapter 5.
Johnson, D.R., 1983, Mercury Inventory Record for Tritium Facilities, Tritium Facilities Sep Tech Memo No. 438, E.I. du Pont de Nemours \& Co., Aiken, SC.

Reinig, W.C., 1989, Action Plan for the Resolution of Findings in the DOE-HQ Environmental Survey of SRS, ESH-EPB-890039, Westinghouse Savannah River Company, Aiken SC.

Roberts, J.S., 1985, NEPA Compliance Memorandum-To-File, Tritium Contaminated Gold Amalgam Disposal, Building 234-H, Special Test Authorization 229," E.I. du Pont de Nemours \& Co., Aiken, SC.

Schmitz, M.A., 1989, Tritium Facilities Mercury Inventory, OPS-TPD-890413, Westinghouse Savannah River Company, Aiken SC.

Tom, S.M., Gold Trap Disposal, 1984, Memo: March 26,1984, Revised April 6, 1984, E.I du Pont de Nemours \& Co., Aiken, SC.

WSRC, 1992 "RFI-RI Work Plan Burial Ground Complex," 1992, WSRC-RP-90-1140, Rev. 1., Westinghouse Savannah River Company, Aiken SC.

WSRC, 1993, Federal Facility Agreement Progress Report (U)," WSRC-RP-93-1155, Westinghouse Savannah River Company, Aiken $\mathrm{SC}$. 
Table 3-1. Mercury in Groundwater Samples During Calendar Year 1992 (Amett et al. 1993)

\begin{tabular}{lccc} 
Location & $\begin{array}{c}\text { Maximum } \\
\text { Result ppm }\end{array}$ & $\begin{array}{c}\text { Wells } \\
\text { Analyzed }\end{array}$ & $\begin{array}{c}\text { Wells } \\
>0.002 \mathrm{ppm}\end{array}$ \\
\hline M-Area Hazardous Waste Management Facility & 0.0024 & 42 & 1 \\
Plume Definition Wells in A/M Area & 0.0034 & 209 & 1 \\
R-Area Reactor Seepage Basin & 0.0080 & 21 & 6 \\
Old SWDF, 643-E & 0.0040 & 37 & 5 \\
SWDF, 643-7E and 643-28E & 0.0026 & 45 & 1 \\
F-Area Seepage Basins & 0.012 & 67 & 6 \\
F-Area Sludge Land Application Site & 0.0058 & 4 & 1 \\
H-Area Seepage Basins - Upper Saturated Zone & 0.0079 & 108 & 15 \\
H-Area Tank Farm & 0.0039 & 32 & 8 \\
TNX Burying Ground & 0.0029 & 5 & 1 \\
Road A Chemical Basin & 0.0027 & 5 & 1 \\
Sanitary Landfill & 0.0029 & 42 & 1 \\
Total Wells & & 617 & 47 \\
\hline
\end{tabular}

Table 3-2. Mercury Use (kg) in the H-Area and F-Area Canyon Facilities by Year ${ }^{(\mathrm{a})}$

\begin{tabular}{lcc} 
Year & $221-\mathrm{H}$ & $221-\mathrm{F}$ \\
\hline 1974 & $3.6 \times 10^{3}$ & $-(\mathrm{b})$ \\
1975 & $4.3 \times 10^{3}$ & - \\
1976 & $3.3 \times 10^{3}$ & - \\
$1977^{(\mathrm{c})}$ & $2.7 \times 10^{3}$ & - \\
1978 & - & - \\
1979 (d) & $2.4 \times 10^{2}$ & - \\
1980 & - & - \\
1981 & - & - \\
1982 & $2.6 \times 10^{3}$ & - \\
1983 & $2.9 \times 10^{3}$ & - \\
1984 & $4.8 \times 10^{3}$ & - \\
1985 & $4.8 \times 10^{3}$ & $6.2 \times 10^{2(\mathrm{e})}$ \\
1986 & $1.5 \times 10^{3}$ & $2.8 \times 10^{2(\mathrm{f})}$ \\
1987 & $1.1 \times 10^{3}$ & $3.0 \times 10^{2}$ \\
1988 & 0 & $6.8 \times 10^{2}$ \\
1989 & 0 & $5.6 \times 10^{2}$ \\
1990 & $(\mathrm{~g})$ & 0 \\
1991 & - & 0 \\
1992 & - & $5.6 \times 10^{1}$ \\
1993 & $(\mathrm{~g})$ & 0 \\
\hline
\end{tabular}

\footnotetext{
(b) A hyphen (-) indicates no information is available.

(c) January to September inclusive.

(d) September only.

(e) March to December inclusive.

(f) August to December inclusive.

(g) Inventory adjustments resulted in a net gain of mercury for the calendar year.
}

(a) Inventory adjustments, presumably due to tank readings, introduce some degree of error in these values. 
Table 3-3. Mercury Use (kg) in the Tritium Facilities

\begin{tabular}{|c|c|c|c|}
\hline Year & Mercury Use (a) & Year & Mercury Use (a) \\
\hline 1960 & $6.0 \times 10^{2}$ & 1974 & $7.7 \times 10^{1}$ \\
\hline 1961 & $9.0 \times 10^{2}$ & 1975 & $7.3 \times 10^{2}$ \\
\hline 1962 & $9.6 \times 10^{2}$ & 1976 & $1.4 \times 10^{1}$ \\
\hline 1963 & $1.3 \times 10^{3}$ & $1977^{(c)}$ & $6.8 \times 10^{1}$ \\
\hline 1964 & $7.3 \times 10^{2}$ & 1978 & - (d) \\
\hline 1965 & $5.3 \times 10^{2}$ & $1979^{(e)}$ & 0 \\
\hline 1966 & $5.0 \times 10^{2(b)}$ & 1980 & - \\
\hline 1967 & $5.0 \times 10^{2(b)}$ & 1981 & - \\
\hline 1968 & $4.8 \times 10^{2}$ & 1982 & $1.0 \times 10^{3}$ \\
\hline 1969 & $2.4 \times 10^{2}$ & 1983 & $4.5 \times 10^{2}$ \\
\hline 1970 & $2.0 \times 10^{2}$ & 1984 & $1.8 \times 10^{2}$ \\
\hline 1971 & $1.5 \times 10^{2}$ & $1985^{(f)}$ & $3.2 \times 10^{1}$ \\
\hline 1972 & $3.8 \times 10^{2}$ & 1986 & - \\
\hline 1973 & $1.3 \times 10^{2}$ & $1987(\mathrm{~g})$ & $3.6 \times 10^{1}$ \\
\hline
\end{tabular}

(a) Tritium facility use for the years $1968-1983$ reportedly contains discrepancies totaling $1.8 \times 10^{3} \mathrm{~kg}$. Of this total, the following explanations are provided: sent to a mercury smelter $\left(3.5 \times 10^{2} \mathrm{~kg}\right)$; sent to a pump manufacturer for testing (45 kg); transferred to other site departments where it presumably would end up as waste $\alpha$ stored excess $\left(2.7 \times 10^{2} \mathrm{~kg}\right)$; unaccountable process inventory, buried residue, or simply unaccounted for, all of which presumably would end up as waste $\left(1.2 \times 10^{3} \mathrm{~kg}\right)$ (Johnson 1983).

(b) Identified as an interpolated average.

(c) January to September inclusive.

(d) A hyphen (-) indicates no information is available.

(e) September only.

(f) January to March inclusive.

(g) June to September inclusive.

Table 3-4. Mercury Air Emissions Inventory for the Savannah River Site (a)

Discharge Points

\begin{tabular}{|c|c|c|c|}
\hline \multirow{2}{*}{20} & \\
\hline & Total & Emissions & No Emissions \\
\hline Process and Production (b) & 40 & 37 & 3 \\
\hline Fuel Combustion & 48 & 47 & 1 \\
\hline Ash Disposal & 5 & 4. & 1 \\
\hline Coal Handling and Crushing & 3 & 3 & 0 \\
\hline Storage Tank & 1 & 1 & 0 \\
\hline Incinerator & 1 & 0 & 1 \\
\hline
\end{tabular}

(a) The SRS Air Emissions Inventory, first completed for calendar year 1990, is being updated. Additional sources of mercury
discharges are anticipated.

(b) Includes reported processing facilities as well as process control, research and calibration laboratories, and support facilities. 
Table 3-5. Specific Mercury Emission Points as Reported in the 1990 Savannah River Site Air Emissions Inventory for Calendar Year 1990

Building/Area

Source Description

736-A

773-A

791-A

FX0044

904-G

241/242-H

222-H

232-H

Sitewide

Process and production

Process and production

Process and production

Storage Tank

Ash Basins

Process and production

Process and production

Process and production

672-T

299-H

Fuel combustion

284/285-H

Process and production

184/185/188/189-K

Process and production

Process and production

Process and production

Table 3-6. Estimated Releases of Mercury from the Combustion of Coal at the Savannah River Site for the Years 1980 - 1993 (a)

\begin{tabular}{cc} 
Year & Mercury Releases $(\mathrm{kg})$ \\
\hline 1980 & $4.8 \times 10^{1}$ \\
1981 & $5.1 \times 10^{1}$ \\
1982 & $4.7 \times 10^{1}$ \\
1983 & $5.0 \times 10^{1}$ \\
1984 & $4.9 \times 10^{1}$ \\
1985 & $5.0 \times 10^{1}$ \\
1986 & $4.8 \times 10^{1}$ \\
1987 & $4.9 \times 10^{1}$ \\
1988 & $4.1 \times 10^{1}$ \\
1989 & $2.5 \times 10^{1}$ \\
1990 & $2.6 \times 10^{1}$ \\
1991 & $2.2 \times 10^{1}$ \\
1992 & $2.6 \times 10^{1}$ \\
1993 & $2.4 \times 10^{1}$ \\
\hline
\end{tabular}

(a) The average concentration of mercury in coal is estimated by the vendor to be $0.12 \mathrm{ppm}$. 
Table 3-7. Mercury in Par Pond and Pond C Sediment (Amett et al. 1992)

\begin{tabular}{llc} 
Sample Date & Sample ID & Mercury Conc. (ppm) \\
\hline $7 / 30 / 91$ & Pond C & $<0.0001$ \\
$8 / 15 / 91$ & Composite 1 & 0.176 \\
$8 / 15 / 91$ & Composite 2 & 0.051 \\
$8 / 15 / 91$ & Composite 3 & 0.055 \\
& & \\
$9 / 4 / 91$ & Composite 1 & $<0.0001$ \\
$9 / 4 / 91$ & Composite 2 & 0.032 \\
$9 / 4 / 91$ & Composite 3 & 0.040 \\
$9 / 4 / 91$ & Composite 4 & 0.026 \\
\hline
\end{tabular}

Table 3-8. Mercury in Fish (Amett et al. 1992)

\section{Concentration in Flesh (ppm)}

\begin{tabular}{|c|c|c|}
\hline & & \\
\hline Sample Location & Maximum & Average \\
\hline Savannah River - Upriver & 1.28 & 0.34 \\
\hline Savannah River - Adjacent & 1.61 & 0.48 \\
\hline Savannah River - Downriver & 2.06 & 0.23 \\
\hline Par Pond & 1.63 & 0.62 \\
\hline Pond B & 1.99 & 0.72 \\
\hline Lower Three Runs Creek & 1.69 & 0.98 \\
\hline Steel Creek & 2.26 & 0.88 \\
\hline Pen Branch & 0.76 & 0.35 \\
\hline Beaver Dam Creek & 0.45 & 0.14 \\
\hline Upper Three Runs - 4 & 1.01 & 0.38 \\
\hline Upper Three Runs - Hwy 278 & .48 & 0.33 \\
\hline Fourmile Branch & 1.13 & 0.65 \\
\hline Thurmond Lake & 1.51 & 0.83 \\
\hline
\end{tabular}




\section{Chapter 4.}

\section{Mercury Concentration and Transport Mechanisms}

This chapter presents information on the concentration of mercury on the Savannah River Site. It will also discuss the various forms of mercury and investigate the mechanisms of transport on the site. 
This page intentionally left blank. 


\section{Transport of Mercury at the SRS}

Table 4-1 lists typical natural and anthropogenic sources and compares their annual emissions.

Table 4-1. Releases of Mercury to the Environment (U.S. Public Health Service 1989)

\begin{tabular}{lll}
\hline Source - Examples & Annual Release $(\mathrm{kg})$ \\
\hline Global Degassing - & Volcanic Activity & $2.5 \times 10^{7}$ to $1.5 \times 10^{8}$ \\
& Westhering of Rocks & \\
Anthropogenic - & Agriculural Products & $2.0 \times 10^{6}$ to $3.0 \times 10^{6}$ \\
& Chlor-alkali plants \\
& Fossil Fuel Combustion \\
& Landfills \\
& Metal Smelting \\
& Paints and Inks \\
& Paper Mills \\
& Pharmaceuticals
\end{tabular}




\section{Transport in Air}

Mercury has three valence states and is found as inorganic and organic compounds in addition to the elemental (liquid) form. Some forms have sufficient vapor pressure to volatize from soil and water. Mercury can travel in the atmosphere, in surface and groundwaters, adhere to soils and sediments, and bioaccumulate. Environmental factors that affect how mercury will be present and transported include redox potential, $\mathrm{pH}$, presence of complexing agents (such as chlorine and sulfur compounds), number and type of microorganisms present, nutrient loading (for microorganism activity), organic solvents present, and organic matter present.

A simplified representation of mercury's pathways in the environment is shown in Figure 4.1.
Elemental mercury, the most reduced form and a liquid at standard conditions, easily volatizes and plays a significant role in atmospheric transport. Mercury in the atmosphere also attaches to and is carried along with particulates. Approximately 1,000 metric tons of mercury are present in the atmosphere world-wide at any one time (U.S. Public Health Service 1989). Once the mercury is released, residence time in the atmosphere is estimated to range from six days to two years (U.S. Public Health Service 1989). Elemental mercury vapor and volatile compounds can remain airborne and travel considerable distances, while compounds that are less volatile or bound to particulates will deposit nearer the release point.

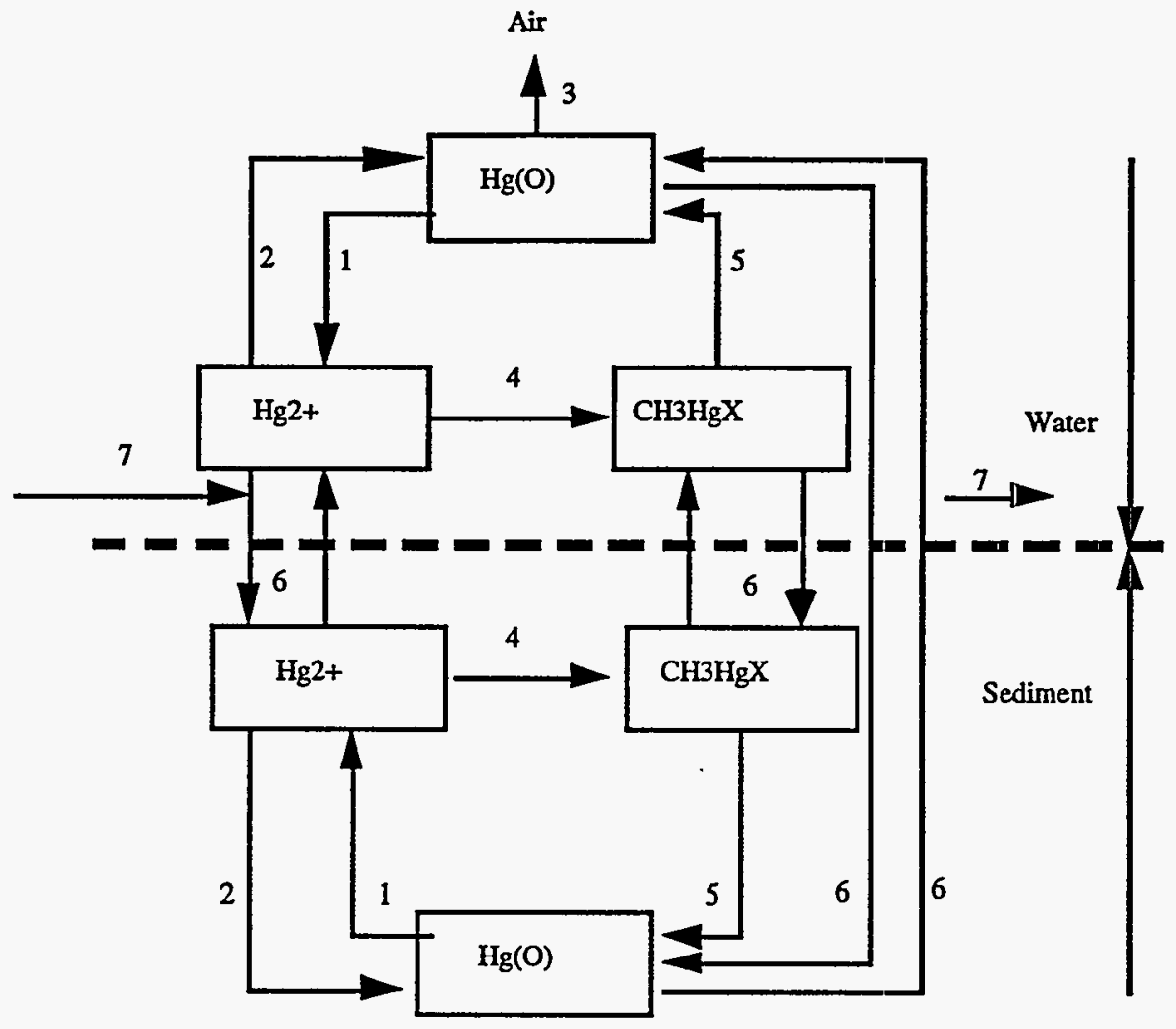

Figure 4.1. Schematic Representation of the Components, Transformations, Exchanges, and Transport Pathways of Mercury. 1 -Oxidation; 2 -Reduction; 3 -Volatization; 4 - Methylation; 5 -Demethylation; 6 -Sediment-v/ater Exchange;

7 - Flow Dispersion. (Carden et al., 1984) 


\section{Groundwater Concentrations and Transport}

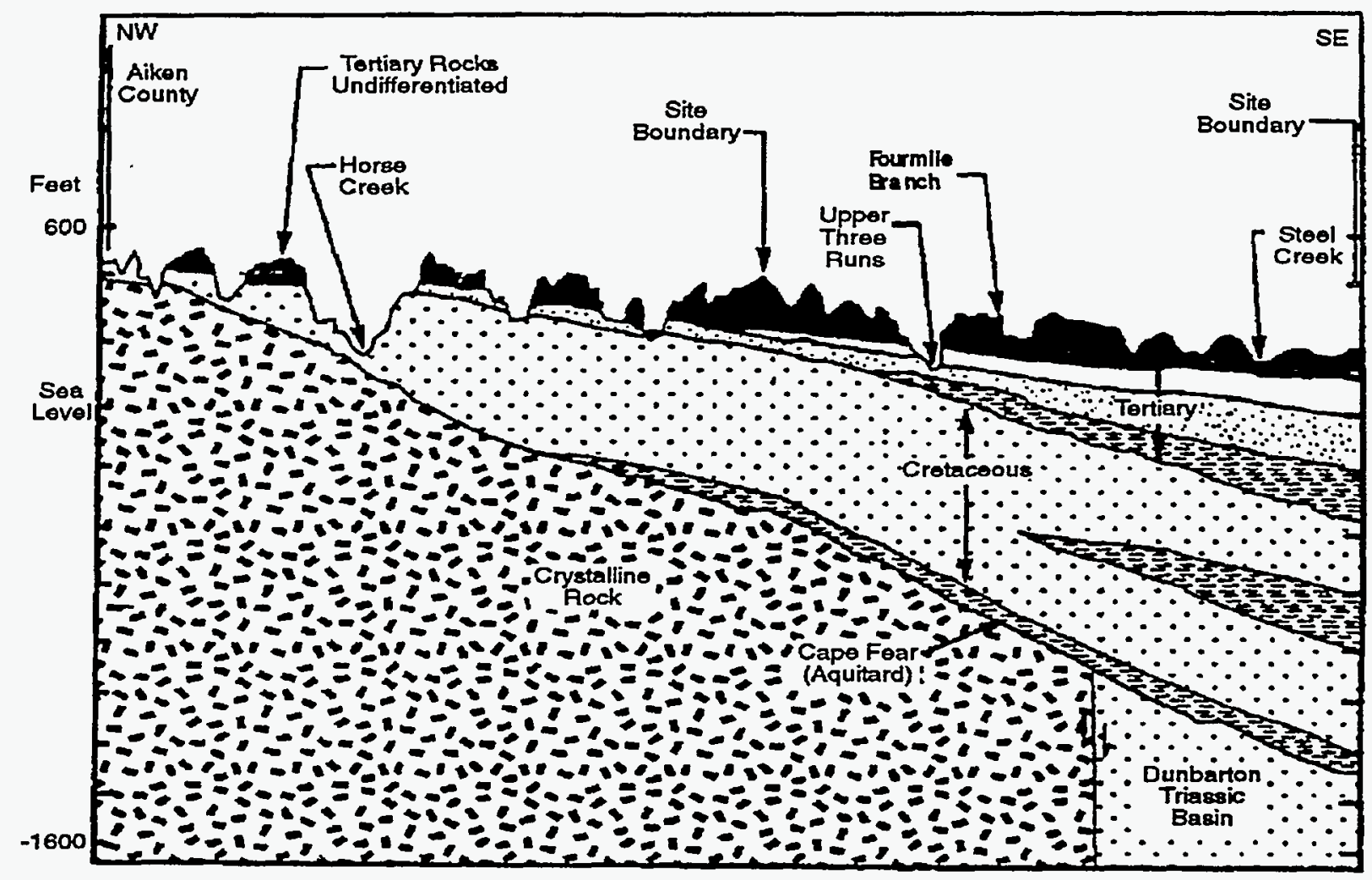

Figure 4.2 Geological Cross-Section Showing the Main Aquifers

\section{SRS Groundwater System}

SRS lies on the Atlantic Coastal Plain, about $32 \mathrm{~km}$ southeast of the edge of the Piedmont Physiographic Province. The Coastal Plain is underlain by a seaward-dipping wedge of sediments that thins to the northwest where it contacts the exposed crystalline rocks of the Piedmont (Figure 4.2). The sediments of interest in this report are those of Cretaceous or younger age that contain the aquifers that supply much of the drinking water for the area surrounding the Savannah River Site. These sediments were deposited in shallow marine to fluvial environments (Gohn 1988) and consist of interbedded sands and clays with minor occurrences of calcareous rocks.

The stratigraphic names applied to the various units have been modified as more detailed information has become available. Figure 4.3 compares some of the changes that have occurred in the hydrostratigraphic nomenclature since the mid-1960s. The current nomenclature (Aadland et al. 1992) takes into account the progressive thickening of the aquifers across the site and the effectiveness of the confining units that separate the aquifer units. The recent changes avoid tying the aquifer nomenclature to the lithostratigraphic names and extend existing hydrostratigraphic nomenclature from surrounding regions into SRS. A map view, Figure 4.4, shows the approximate limits of the coastal plain aquifer systems across the SRS.

At the base of the Coastal Plain sediments is an aquitard, the Appleton Confining System, composed of residual soils of the basement rocks and dense clays of the Cape Fear Formation. Overlying this confining unit are two aquifers in Cretaceous sands, McQueen Branch and Crouch Branch. Generally these sands are considered to be prolific water producers and are the source for most of the water 


\begin{tabular}{|c|c|c|c|c|c|c|}
\hline & 1967 & 1967 & \multicolumn{3}{|c|}{1990} & 1969 \\
\hline \multirow{7}{*}{ 䍣 } & Hawhorn Aquiler & \multirow{5}{*}{$\begin{array}{l}\text { Tertiany } \\
\text { Sand } \\
\text { Aquiler }\end{array}$} & \multicolumn{3}{|c|}{ Upland Uhit } & \multirow{2}{*}{$\begin{array}{l}\text { Upland Univ } \\
\text { Hawthom }\end{array}$} \\
\hline & Bamwell & & 월 & \multicolumn{2}{|c|}{ Tobacoo Rd Formation } & \\
\hline & McBean Aquiler & & 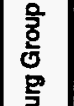 & $\begin{array}{l}\text { Dry Branch } \\
\text { Formation }\end{array}$ & $\begin{array}{l}\text { Clinchifield Sand Mbr } \\
\text { Griffins Londing Mbr } \\
\text { Irwinton Sand Mbr } \\
\text { Twiggs Clay Mbr }\end{array}$ & Banwell \\
\hline & \multirow[t]{2}{*}{ Congaree Aquiler } & & 효효 & \multicolumn{2}{|c|}{$\begin{array}{l}\text { McBean Formation } \\
\text { Green Clay }\end{array}$} & MoBoun $\sum$ Santeo \\
\hline & & & o & \multicolumn{2}{|c|}{ Congaree Formation } & Congaroe Wartey \\
\hline & \multirow{2}{*}{$\begin{array}{l}\text { Ellenton } \\
\text { Aquitard }\end{array}$} & \multirow{2}{*}{$\begin{array}{c}\text { Confining } \\
\text { Uni }\end{array}$} & \multirow{2}{*}{ 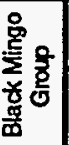 } & \multicolumn{2}{|c|}{ Williamsburg Formation } & Black Mingo \\
\hline & & & & \multicolumn{2}{|c|}{ Elenton Formation } & Elenton Formation \\
\hline \multirow{4}{*}{ 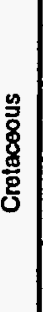 } & $\begin{array}{c}\text { Upper Tuscaboosa } \\
\text { Aquifer }\end{array}$ & $\begin{array}{l}\text { Black Creek } \\
\text { Aquiter }\end{array}$ & \multirow{3}{*}{ : } & \multicolumn{2}{|c|}{ Peodeo Formation } & Peodoe Formation \\
\hline & $\begin{array}{l}\text { Mid Tuscaloosa } \\
\text { Clay Aquilard }\end{array}$ & $\begin{array}{l}\text { Confining } \\
\text { Uni }\end{array}$ & & \multicolumn{2}{|c|}{ Black Croek Formation } & Black Crook Formation \\
\hline & $\begin{array}{c}\text { Lower Tuscaloasa } \\
\text { Aquifer }\end{array}$ & $\begin{array}{l}\text { Middandoff } \\
\text { Formation }\end{array}$ & & \multicolumn{2}{|c|}{ Middendorf Formation } & Middendorf Formation \\
\hline & $\begin{array}{l}\text { Basal Clay } \\
\text { Aquitard }\end{array}$ & $\begin{array}{l}\text { Confining } \\
\text { Unit }\end{array}$ & \multicolumn{3}{|c|}{ Capo Fear Formation } & Cape Fear Formation \\
\hline
\end{tabular}

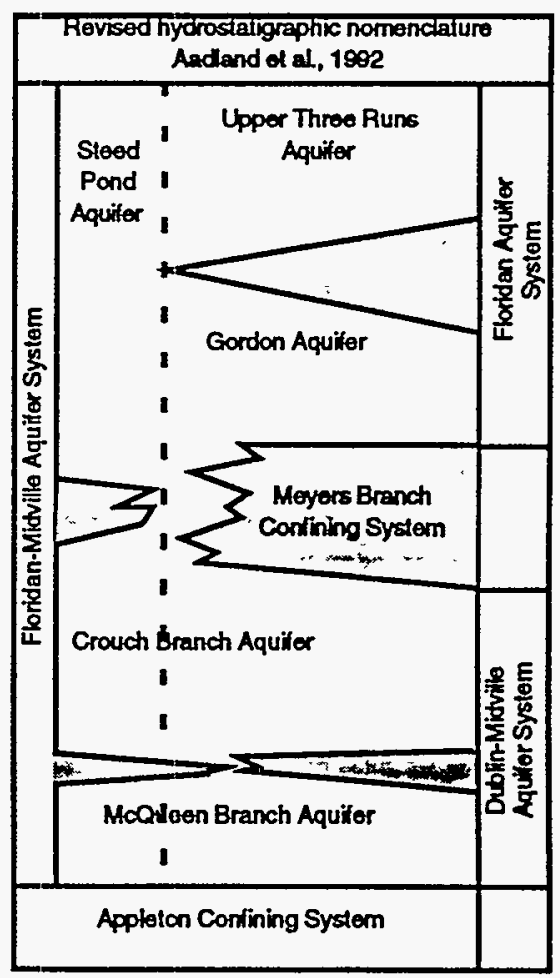

Figure 4.3 Stratigraphic and Hydrostratigraphic Nomenclature Used on the Savannah River Site

supply wells on the site. They are separated from each other by the relatively less permeable beds that make up the Black Creek Formation.

The Tertiary aquifers are separated from the underlying Cretaceous aquifer units by confining beds of the Black Mingo Group, especially the Ellenton Formation. On the northwestern corner of site, the separation is not as effective as in the southern portion.

In the southeastern area, the Tertiary section can be divided into two separate aquifers, the Gordon (formerly called the "Congaree Aquifer") and Upper Three Runs (frequently referred to as the "Barnwell Aquifer" or "Watertable Aquifer"). The aquitard or confining bed that separates these two units is a glauconitic clayey zone of the McBean Formation locally referred to as the "green clay." This clay pinches out and becomes more sandy toward the northwest.

In some areas of the site, it is necessary to modify the hydrostratigraphic nomenclature because of local changes in lithologies and topography. For example, in some portions of the site, an aquitard unit referred to as "tan clay" subdivides the uppermost aquifer into two separate zones. In the southern portion of the site, the "tan clay" unit is thin or sporadic and does not form a consistent aquitard.

The water table level is controlled primarily by local topographic features. The surface of the Atlantic Coastal Plain at the site is a relatively flat plateau (the Aiken Plateau) dissected by stream erosion. The incision of the streams has left relatively isolated, flat-lying surfaces separated by 27- to 38-meter deep stream valleys. The depth to the water table below land surface varies from $0 \mathrm{~m}$, when it outcrops in the stream valleys or wetlands, to $38 \mathrm{~m}$ below the remnant plateau areas. The water table depth usually is controlled by the elevation of the nearest Savannah River tributary stream. At many localities on site, the water table is situated in Tertiary sediments of low water-producing capabilities, and perched water tables exist sporadically across the site.

The direction of groundwater flow at any locality may change or even reverse in successively deeper aquifers. The aquifers in the Tertiary sediments receive local recharge, and flow generally is toward nearby stream valleys. Typically, flow at the water table is toward minor tributaries, while deeper Tertiary aquifers flow toward major tributaries of the Savannah River. The deepest aquifers at SRS, the Dublin-Midville Aquifer System, receive recharge in the outcrop areas of the Cretaceous sediments north 
of the site. Groundwater flow beneath the site in this system is toward the Savannah River.

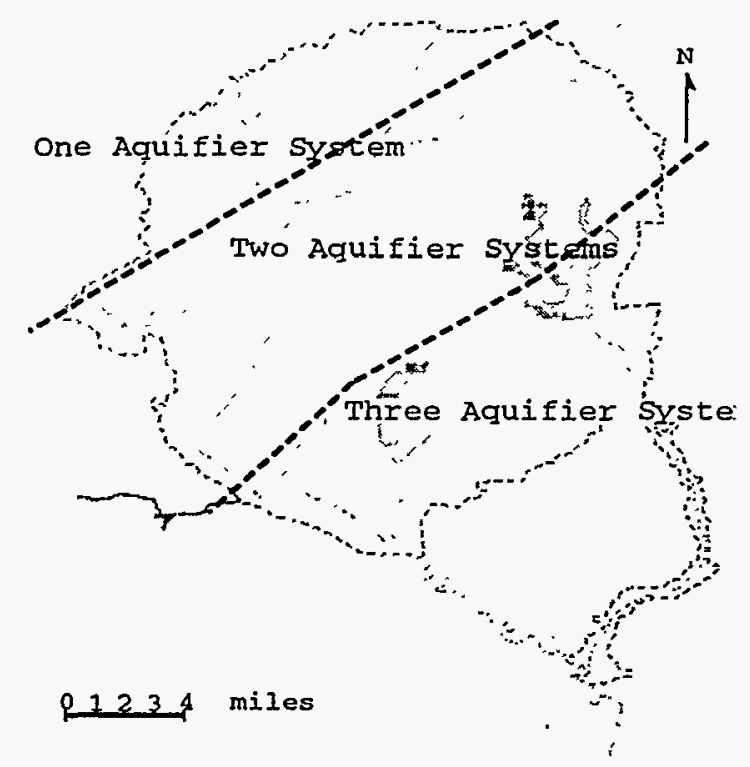

Figure 4.4 Updip Limits of the Confining Systems in the Coastal Plain Sediments

Over much of the site, the potentiometric surface, or hydraulic "head," of the deeper aquifers in the Cretaceous sediments is higher than that of the overlying Tertiary aquifers (Christensen and Gordon 1983). This upward gradient, an important characteristic of many of the waste disposal areas, has provided protection from downward transport of contaminants to the deeper aquifers on the site. Figure 4.5 outlines the areas where there is an upward hydraulic gradient across the confining units near the Cretaceous-Tertiary boundary.

\section{Mercury in SRS Groundwater}

Mercury is widely distributed, but is present at very low concentrations, in the earth's crust. Its average crustal abundance is $0.02 \mathrm{ppm}$ and its average concentration in seawater is approximately $0.00003 \mathrm{ppm}$ (Krauskopf 1979). Generally, mercury is even less concentrated in groundwater. However, because the geochemical behavior of mercury in water is complicated, the chemical composition of groundwater can have a marked effect on the concentration of mercury.

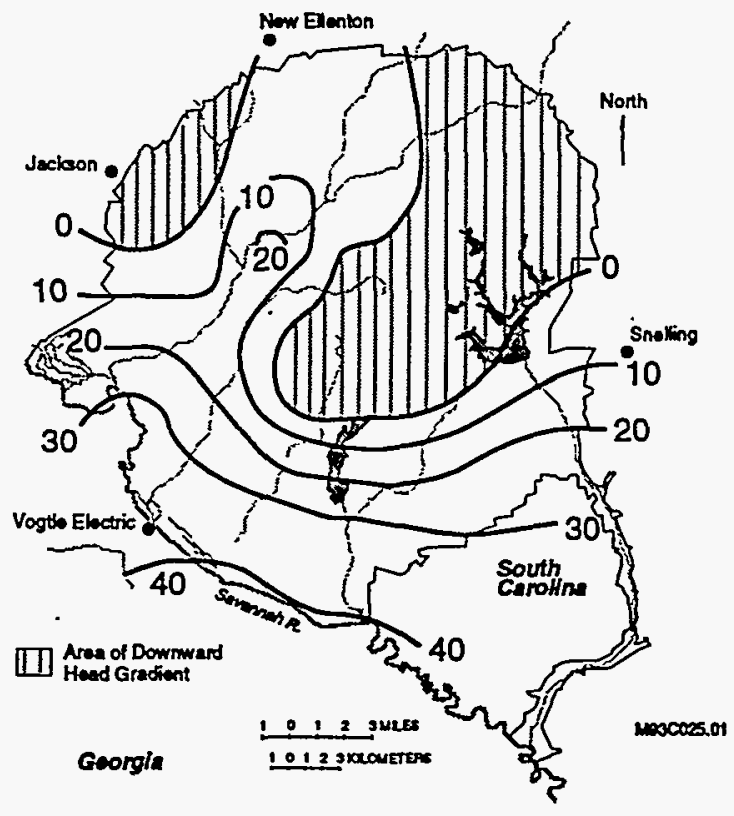

Figure 4.5 Hydraulic Head Differences Across Confining Units Near the Cretaceous/Tertiary Boundary.

Mercury occurs naturally in three oxidation states-the zero valent state and the oxidized forms $\mathrm{Hg}(\mathrm{I})$ and $\mathrm{Hg}$ (II). In the elemental state, at typical near-surface geologic conditions, mercury can exist as the liquid metal, in a vapor phase, or dissolved in water as $\mathrm{Hg}^{\circ}$ (aq). All three of these species can be mobile in soils and groundwater. Though liquid mercury tends to migrate downward in soils, its high surface tension tends to trap it in pore spaces. In the dissolved state, zero valent mercury will migrate with groundwater. Elemental mercury trapped in pore spaces or dissolved in groundwater has a high vapor pressure (relative to most other inorganic contaminants) and will vaporize until equilibrium with the vapor phase is attained. The resulting mercury vapor is mobile in the unsaturated zone, as well as in the atmosphere.

$\mathrm{Hg}(\mathrm{I})$ is probably metastable under most near-surface geologic conditions. In water, this form of mercury occurs as the diatomic ion $\mathrm{Hg}_{2}{ }^{+2}$, which tends to dissociate by the reaction:

$$
\mathrm{Hg}_{2}{ }^{+2}(\mathrm{aq})=\mathrm{Hg}^{0}(\mathrm{aq})+\mathrm{Hg}^{+2}(\mathrm{aq})
$$


In the presence of $\mathrm{Cl}^{-}$or alkaline $\mathrm{pH}, \mathrm{Hg}^{+2}$ is complexed and the reaction is driven to the right. Most groundwater (including that at SRS; Strom and Kaback 1992) has a sufficient $\mathrm{Cl}^{-}$concentration or high enough $\mathrm{pH}$ to render $\mathrm{Hg}_{2}{ }^{+2}$ unstable.

The mobility of $\mathrm{Hg}$ (II) in groundwater depends on the chemical composition of the groundwater and the mineralogy of the aquifer. Mobility can be attenuated by precipitation of mercury minerals or by sorption onto soil phases. When conditions favor the presence of sulfide ions, mercury is immobilized by the precipitation of the insoluble mineral HgS (cinnabar). Mercury hydroxide $\left(\mathrm{Hg}(\mathrm{OH})_{2}\right)$ and mercury oxide also may limit mercury mobility.

Mercury also can occur naturally in organic compounds. Of most concern environmentally are dimethyl mercury $\left[\left(\mathrm{CH}_{3}\right)_{2} \mathrm{Hg}\right]$ and methyl mercury $\left[\left(\mathrm{CH}_{3}\right) \mathrm{Hg}^{+}\right]$. Inorganic species of mercury can be converted to these organic forms by bacteria and fungi (Fergusson, 1990). The organic forms of mercury are relatively mobile in the environment. Methyl mercury is soluble in water and thus mobile in groundwater, while dimethyl mercury is volatile and may be transported as a vapor. A recent study of mercury speciation (Denham and Strom 1994) found no organic forms of mercury in five sediment samples from Par Pond and 18 soil samples from the H-Area mercury plume.

The degree to which a solute such as mercury is sorbed or retained by a soil is described by a distribution coefficient $\left(\mathrm{K}_{\mathrm{d}}\right)$. It is defined as the ratio, at equilibrium, of the amount of a constituent retained by the soil to the amount that remains in solution. The $\mathrm{K}_{\mathrm{d}}$ for a solute such as mercury is controlled by the mineralogy of the soils, the surface chemistry of the grain coatings, and the chemistry of the aqueous phase. For instance, soils that contain iron and manganese oxides, clay minerals, or organic matter tend to retain mercury more effectively than other soils. The adsorptive characteristics vary with solution $\mathrm{pH}$ because $\mathrm{pH}$ influences the net surface charge on mineral grain coatings and other variably charged surfaces. At an acidic $\mathrm{pH}$, the mineral surfaces may have a net positive charge and be relatively inert toward positively charged aqueous species. As $\mathrm{pH}$ increases, the surface charge may become increasingly negative and the minerals may more strongly adsorb positively charged species. In other words, the distribution coefficient $\left(\mathrm{K}_{\mathrm{d}}\right)$ can vary as a function of the solution $\mathrm{pH}$ and its effect on the properties of the mineral grain surfaces.

The solution chemistry also affects the distribution coefficient by influencing the speciation of contaminant ions and the formiation of complex ions. For example, mercury in the aqueous form $\mathrm{Hg}(\mathrm{OH})_{2}$ is strongly attenuated by soils, but the species $\mathrm{Hg}(\mathrm{Cl}) 2^{\circ}$ is not strongly attenuated. Research on mercury sorption shows that the presence of chloride decreases adsoiption of mercury on iron hydrous oxide gel (Kinniburgh and Jackson 1978), goethite (Forbes et al. 1974), and quartz (MacNaughton and James 1974). Andersson (1970) found that chloride decreased mercury adsorption on soils more effectively than nitrate, phosphate, and sulfate. Two studies at SRS concluded that a portion of the mercury in groundwater was mobile because of acidic conditions and chloride complexing (Looney 1994; Denham and Strom 1994).

\section{General Separation Area Seepage Basins}

During the period 1954 - 1988, seepage basins were used at SRS for the disposal of wastewater containing low concentrations of chemicals and radionuclides. The seepage basins were intended to delay the release of radionuclides that could not otherwise be contained and to allow time for radioactive decay to decrease the activity (Reichert 1968). Several of these basins were located in the separation area near F Area and $\mathrm{H}$ Area (Figure 4.6).

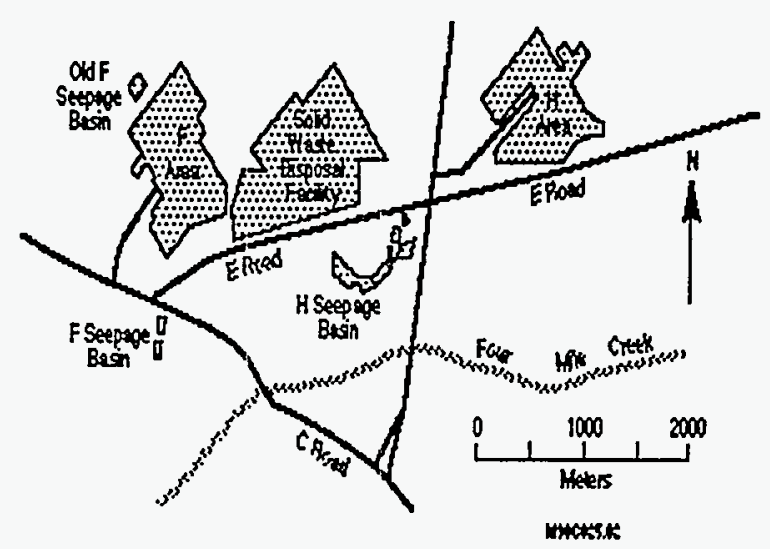

Figure 4.6 Location Map of Waste Disposal Sites in the General Separations Area.

\section{F-Area Seepage Basins}

The first seepage basin on site was constructed in 1954 , just north of $F$ Area, but the seepage rate was inadequate to handle the volume of wastewater coming from the F-Area facilities. Three additional basins constructed south of $F$ Area, received effluent during the period 1954 - 1988. Water infiltrating from the F-Area seepage basins encountered a perched water table 5 to $8 \mathrm{~m}$ below the surface, then 
a normal water table at a depth of 18 to $20 \mathrm{~m}$ below the land surface. This water produced a contamination plume that can be identified in monitor wells by its high conductivity and tritium activities. Flow of water in the water table aquifer is toward Fourmile Branch (also known as Four Mile Creek) at a rate estimated to be about $15 \mathrm{~cm} /$ day (Stone and Christensen 1983). Some of this water intersects the surface at a seepline along Fourmile Branch (Looney et al. 1988).

In some groundwater monitoring wells downgradient from the F-Area Seepage Basins, the Environmental Monitoring Section (EMS) of the Environmental Protection Department of SRS has measured mercury concentrations above the EPA Primary Drinking Water Standard (PDWS) of $0.002 \mathrm{ppm}$. In the time period of first quarter 1992 through second quarter 1993, the highest mercury concentration measured in these wells was $0.032 \mathrm{ppm}$. However, the average concentration was $0.006 \mathrm{ppm}$ for the five wells that have a history of mercury concentrations above the PDWS.

Three studies in recent years have analyzed for mercury in the groundwater intersecting the surface at the seepline along Fourmile Branch. Looney et al. (1988) found that dissolved mercury concentrations at the seepline, downgradient from F Area, were below detection limits of $0.0001 \mathrm{ppm}$. In a subsequent study, the highest concentration measured by Haselow et al. (1990) was $0.0003 \mathrm{ppm}$. However, this was the only sample of 10 that had a mercury concentration above detection limits of $0.0002 \mathrm{ppm}$. Dixon and Rogers (1994) found a maximum mercury concentration of $0.0005 \mathrm{ppm}$ at the seepline. Based on samples taken upstream from the separation areas, they concluded that this was within the background range. Hence, mercury present in the groundwater downgradient from $\mathrm{F}$ Area has not yet reached the seepline at Fourmile Branch. Figure 4.7 shows the FArea mercury plume as reflected in monitoring well data from fourth quarter 1993.

\section{H-Area Seepage Basins}

The four H-Area seepage basins covered an area of $42,700 \mathrm{~m}^{2}$ and were in use from 1955 to 1988 . Liquids discharged to these basins contained lowlevel radioactivity from the H-Area separation facility. In addition, the effluents to these basins contained heavy metals, nitrate in the form of $\mathrm{HNO}_{3}$, and $\mathrm{NaOH}$ (Killian et al. 1985). The basins were closed in 1988 and have since since been capped.
Though in close proximity to the F-Area basins, the hydrogeology at the $\mathrm{H}$-area basins is distinct. The depth of the water table is only about $6 \mathrm{~m}$, and the basins are located closer to the groundwater discharge zone along Fourmile Branch. Much of the groundwater flow in this area of the site appears to occur in narrow, high-permeability channels in the sediments. While a small percentage of the seepage basin waters penetrates into a deeper aquifer, the majority of the waters migrate to the seepline adjacent to Fourmile Branch.

EMS has measured mercury in groundwater from several monitoring wells downgradient from the $H$ Area seepage basins. Among wells having a history of mercury concentrations above the PDWS, the average mercury concentration (from first quarter 1992 through second quarter 1993) was $0.0035 \mathrm{ppm}$, with a maximum concentration of $0.0079 \mathrm{ppm}$.

The three studies that analyzed for mercury in groundwater downgradient from F Area, along the Fourmile Branch seepline, made similar measurements downgradient from H-Area. The maximum concentration of dissolved mercury measured by Looney et al. (1988) was $0.0015 \mathrm{ppm}$. No mercury concentrations above the detection limit of $0.0002 \mathrm{ppm}$ were measured by Haselow et al. (1990). Dixon and Rogers (1994) found elevated concentrations of mercury in groundwater from three locations along the seepline. The highest concentration they measured was $0.0017 \mathrm{ppm}$ (an average of three analyses). Contoured monitoringwell data from fourth quarter 1994 shows the intersection of the H-Area mercury plume with the seepline along Fourmile Branch (Figure 4.8).

The presence of mercury in groundwater at the seepline is consistent with the results of Denham and Strom (1994). They analyzed soils from the H-Area mercury plume for total mercury and mercury speciation and found that mercury was present at low total concentrations and only in mineralogically bound forms. They concluded that chloride complexing and dissolution of adsorption sites by the acidic plume significantly diminished mercury adsorption by the soils, rendering mercury mobile in the groundwater.

\section{Solid Waste Disposal Facility}

At SRS, solid radioactive waste is stored at a single, centrally located Solid Waste Disposal Facility between $\mathrm{F}$ and $\mathrm{H}$ separation areas (Figure 4.6). The original $310,000 \mathrm{~m}^{2}$ burial site operated from 1953 until 1972 and is designated as 643-E (Old Burial 
Ground). A second area, of $480,000 \mathrm{~m}^{2}$ later was opened to receive solid radioactive wastes and was designated as 643-7E (New Burial Ground).

The new SWDF is located on a water table divide. The groundwater beneath about half of the 643-7E area and the groundwater beneath the old SWDF flows south toward Fourmile Branch. Beneath the northern half of the 643-E SWDF, the groundwater flows toward Upper Three Runs Creek.

Mercury has been detected regularly in several wells that monitor groundwater from beneath the 643-E area. During the time period first quarter 1992 through second quarter 1993, the highest mercury concentration measured in these wells was 0.0046 $\mathrm{ppm}$. In wells in which mercury is regularly detected, the average concentration during the same time period was $0.0017 \mathrm{ppm}$. Measurements of mercury vapor adsorbed onto soils of the SWDF found areas of relatively high concentration ( $>8 \mathrm{ppm}$ ) above known mercury disposal locations (Price and Cook
1988). This indicates that the elemental mercury disposed at these locations is mobile in the vapor phase.

\section{Other Measurements of Mercury at SRS}

Concentrations of mercury above the PDWS have been measured in other areas during the quarterly groundwater monitoring performed by EMS. Groundwater from several of the wells that monitor the R-Area seepage basins periodically has mercury concentrations that exceed the PDWS. From first quarter 1992 through second quarter 1993, the highest reported mercury concentration in these wells was $0.0056 \mathrm{ppm}$. Samples from some wells monitoring the M-Area Hazardous Waste Management Facility and the TNX Burying Ground also have concentrations of mercury that periodically exceed the PDWS. 


\section{SAVANNAH RIVER SITE MERCURY CONTENT}

Quarter 4, 1993 Water Table Aquifer

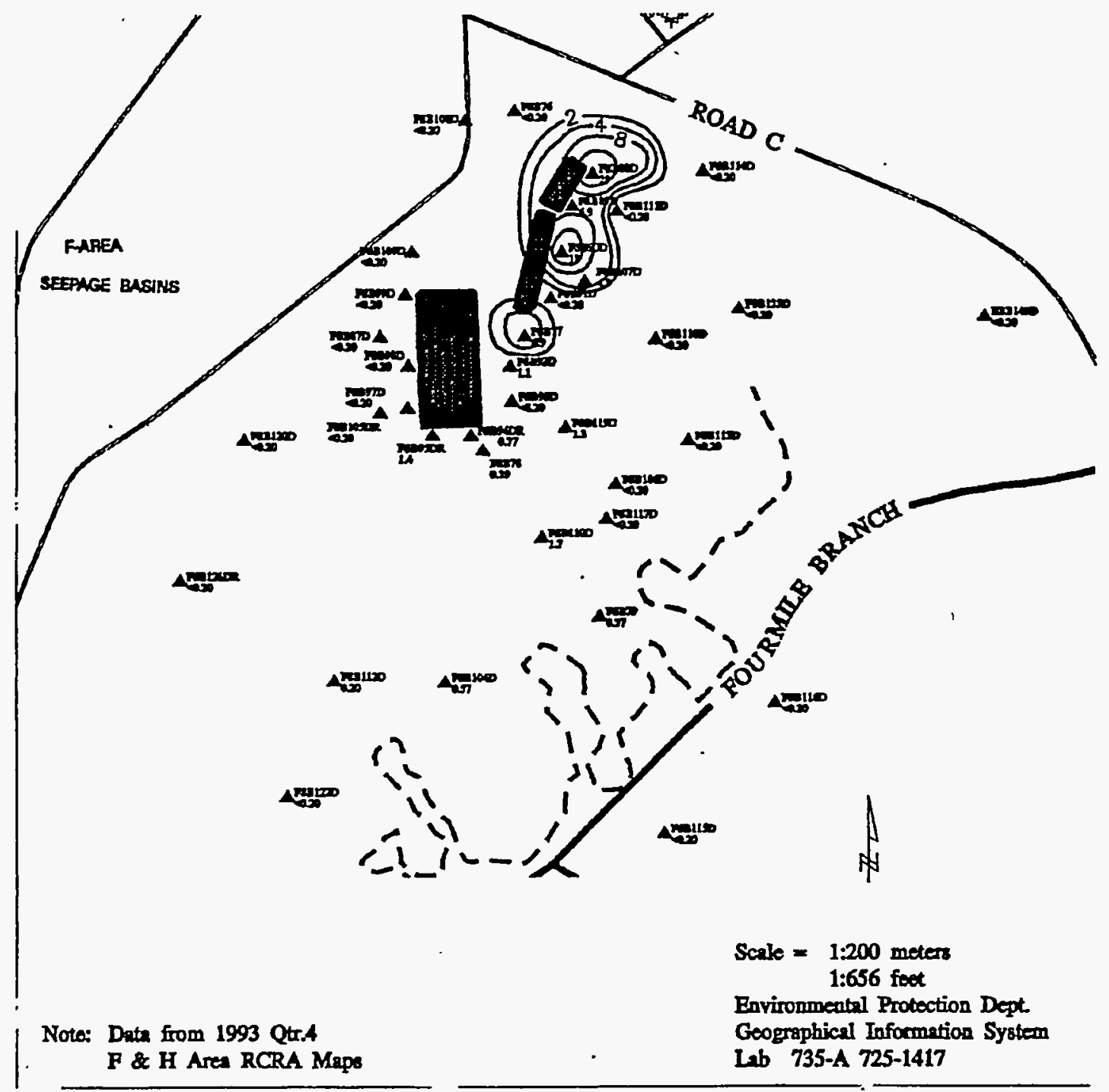

Figure 4.7 Contours of Mercury Concentration in the Groundwater of the Water Table Aquifer near F-Area Seepage Basins (Monitoring Well Data from Fourth Quarter 1993). 


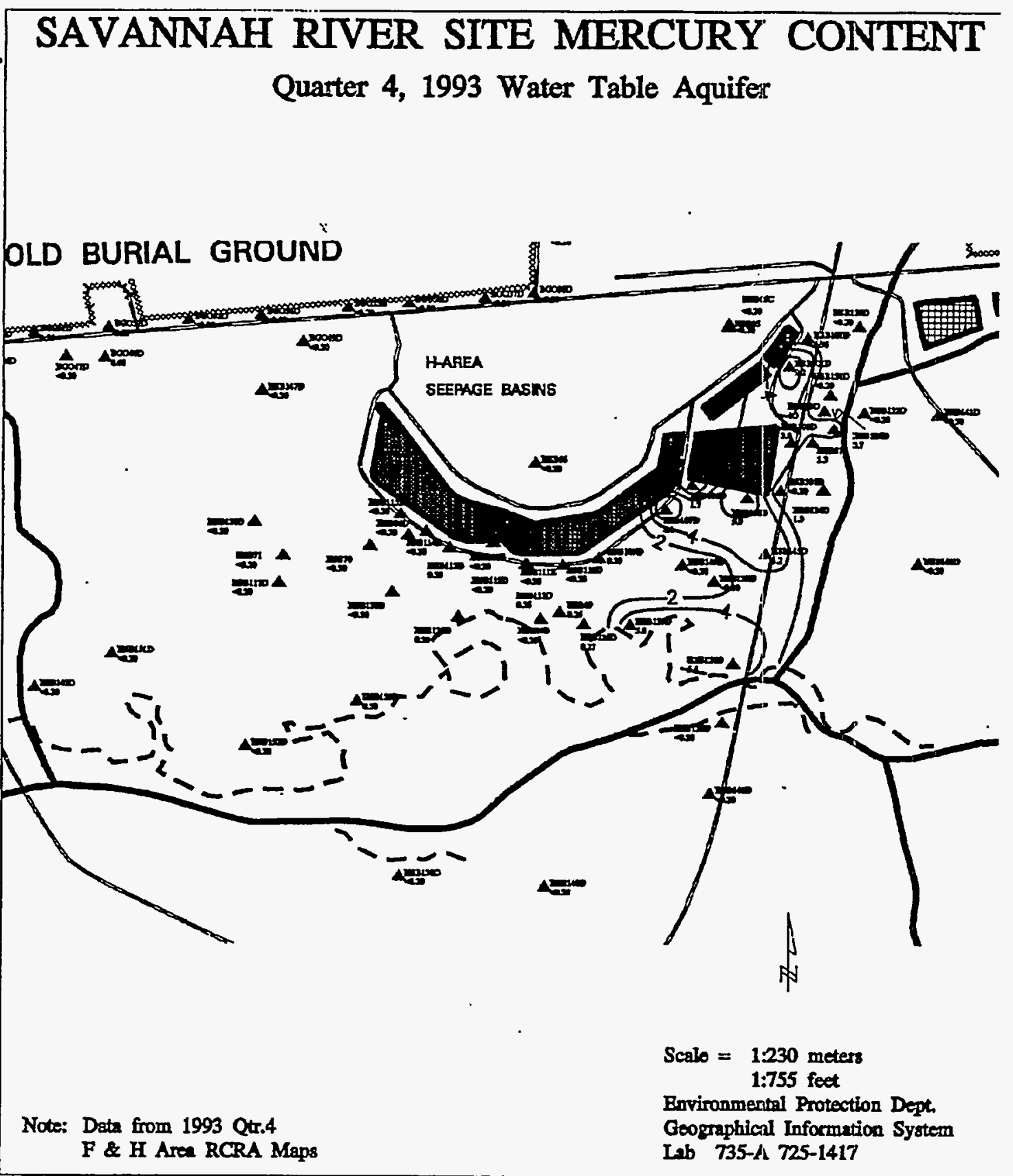

Figure 4.8

Contours of Mercury Concentration in the Groundwater of the Water Table Aquifer near H-Area Seepage Basins (Monitoring Well Data from Fourth Quarter 1993).

\section{References}

Aadland, R.K., P.A. Thayer, and A.D. Smits, 1992, Hydrostratigraphy of the Savannah River Site Region, South Carolina and Georgia, in Wallace Fallaw and Van Price, eds: Geological Investigations of the Central Savannah River Area, South Carolina and Georgia, Carolina Geological Field Trip Guide
Book, Nov. 13-15, 1992, South Carolina Geological Survey, Harbison Forest Road, Columbia, SC, pp. CSG-B-X-1 to 6.

Andersson, A., 1970, On the Geochemical Behavior of Mercury, Grundforbattring, v. 23, p. 31-44. 
Carden, J.L., R. Kury, and G.G. Eichholz, 1984, Mercury Migration into Ground Water, A Literature Study Prepared for the Savannah River Laboratory, Topical Report - Project E26-602, CORR 84-00054, E.I. du Pont de Nemours \& Co. Aiken, SC.

Christensen, E.J., and DE. Gordon, 1983, Technical Summary of Groundwater Quality Protection Program at Savannah River Plant, Volume 1, DPST83-829, E.I. du Pont de Nemours \& Co., Savannah River Laboratory, Aiken, SC.

Denham, M.E., and R.N. Strom, 1994, Mercury Speciation Analyses of $\mathrm{H}$-Area Soil Samples, SRTESS-94-310, Westinghouse Savannah River Company, Aiken, SC.

Dixon, K.L. and V.A. Rogers, 1994, Semiannual Sampling of Four Mile Creek and Its Seeplines in the F- and H-Areas of SRS: July 1992, WSRC-TR-93289, Westinghouse Savannah River Company, Aiken, SC.

Fergusson, J.E., 1990, The Heavy Elements -Chemistry. Environmental Impact. and Health Effects, Pergamon Press, Oxford.

Forbes, E.A., A.M. Posner, and J.P. Quirk, 1974, The Specific Adsorption of Inorganic $\mathrm{Hg}$ (II) Species and Co (III) Complex Ions on Goethite, L. Colloid Interface Sci. v. 49, pp. 403-409.

Gohn, G.S., 1988, Late Mesozoic and Early Cenozoic Geology of the Atlantic Coastal Plains; North Carolina to Florida, The Geology of North America. Boulder, Colo., Geologic Society of America, pp, 107-130.

Haselow, J.S., M. Harris, B.B. Looney, N.V. Halverson, and J.B. Gladden, 1990, Analysis of Soil and Water at the Four Mile Creek Seepline Near the F\&H Areas of SRS (U), WSRC-RP-90-0591, Westinghouse Savannah River Company, Aiken, SC.

Killian, T.H., N.L. Kolb, P. Corbo, and I.W. Marine, 1985, Environmental Information Document - HArea Seepage Basins, DPST-85-706, E.I. du Pont de Nemours \& Co., Savannah River Laboratory, Aiken, SC.

Kinniburgh, D.G., and M.L. Jackson, 1978, Adsorption of Mercury (II) by Iron Hydrous Oxide Gel, Soil Sci. Soc, Am. J, v. 42, pp. 45-47.
Krauskopf, K.B., 1979, Introduction to Geochemistry, McGraw-Hill Book Company, New York.

Looney, B.B., 1994, Scoping Calculation on Potential Mercury Migration from Spill (Process Water Entry Flange) Near Building 672T, SRT-ESS94-124, Westinghouse Savannah River Company, Aiken, SC.

Looney, B.B., J.E. Cantrell, and J.R. Cook, 1988, Sampling and Analysis of Surface Water in the Vicinity of the $F$ - and H-Area Seepage Basins, DPST-88-229, E.I. du Pont de Nemours \& Co., Savannah River Laboratory, Aiken, SC:

MacNaughton, M.G., and R.O. James, 1974, Adsorption of Aqueous Mercury Complexes at the Oxide/water Interface, L. Colloid Interface Sci, v. 47, pp. 431-440.

Price, V., and J.R. Cook, 1988, Mercury in Shallow Savannah River Plant Soil, DPST-86-314, E.I. du Pont de Nemours \& Co., Savannah River Laboratory, Aiken, SC.

Reichert, S.O., 1968, Geology Plays an Important Role in Radioactive Waste Management, Mining Engineering, September 1968, pp. 98-103.

Stone, J.A., and E.J. Christensen, 1983, Technical Summary of Groundwater Quality Protection Program at Savannah River Plant, Volume II Radioactive Waste, DPST-83-829, E.I. du Pont de Nemours \& Co., Savannah River Laboratory, Aiken, SC.

Strom, R.N., and D.S. Kaback, 1992, SRP Baseline Hydrogeologic Investigation: Aquifer Characterization -. Groundwater Geochemistry of the Savannah River Site and Vicinity, WSRC-RP-92450, Westinghouse Savannah River Company, Aiken, SC.

U.S. Public Health Service, 1989, Toxicological Profile for Mercury, PB90-181256, Agency for Toxic Substances and Disease Registry, U.S. Public Health Service. 
This page intentionally left blank 


\section{Chapter 5. Environmental Research on Mercury by Savannah River Ecology Laboratory}

More than 20 Savannah River Ecology Laboratory (SREL) reports and publications pertinent to mercury $(\mathrm{Hg})$ have been generated during the last two decades. In this report, they are divided into three groupings: SRS-specific studies, basic studies of bioaccumulation, and basic studies of effect. 
This page intentionally left blank. 


\section{Overview}

SRS-specific studies include sitewide surveys such as the Comprebensive Cooling Water (CCW) Study (Newman 1986) and a recent survey of mercury bioaccumulation in mosquitofish on and around the SRS (Newman and Messier 1994). SRS-specific studies also include those focused on particular systems, such as Par Pond (Clay et al. 1974; Giesy and Pinder [unpublished], Pinder and Giesy 1981a, b; and Longhi 1990) and Upper Three Runs Creek (mercury bioaccumulation in dusky shiner, as reported in the appendix of Newman and Messier 1994, and mercury in Upper Three Runs Creek water, as reported here).

Basic bioaccumulation studies began with an EPAfunded study of mercury fate using artificial streams built in B Area (Kania and Beyers 1974; Kania et al. 1976; Sigmon et al. 1977; and Kania 1981). Bioaccumulation was assessed for periphyton, macrobenthic invertebrates, an emergent macrophyte, and the mosquitofish (Gambusia holbrooki, formerly G. affinis). After an interval of more than a decade, interest and funding returned to mercury bioaccumulation studies using mosquitofish (Newman and Doubet 1989; Brisbin et al. 1990; and
Brisbin and Newman 1991). An active SREL research program exists in this area today, with a goal of developing this common, widespread fish as a sentinel species of metal bioaccumulation by SRS aquatic biota.

Basic-effects studies began with the EPA-funded artificial streams program. Topics addressed by this program ranged from mercury effects on mosquitofish avoidance of predators (Kania and O'Hara 1974) to algal and insect community responses to mercury (Kania and Beyers 1974; Kania et al. 1976; Sigmon et al. 1977; and Kania 1981). Consistent with SREL's long-term goal of developing the mosquitofish as an SRS sentinel species of contaminant bioaccumulation and effects is an ongoing series of SREL studies of mercury. To date, the focus has been mercury effects on biochemical (Kramer et al. 1992a, b, Kramer and Newman 1994), genetic (Diamond et al. 1989,1991; Heagler et al. 1993; Kramer et al. 1992a; Kramer and Newman 1994; Lee et al. 1992; Mulvey et al. submitted, and Newman et al. 1989), and demographic (Lee et al. 1992; Heagler et al. 1993; Mulvey et al. submitted) qualities.

\section{SRS-Specific Studies}

\section{SRS-Wide Studies}

During the CCW Study, SREL monitored mercury concentrations at 34 sites monthly from November 1 , 1983, to August 21, 1985. Mercury was not detected in any of the SRS systems or the Savannah River using a mandated standard method with a high detection limit (0.0001 ppm) (Newman 1986).

An SREL study (Newman and Messier 1994) recently asked the question, "Do fish from the SRS have mercury concentrations significantly higher than fish from nearby offsite locations?" This study was prompted by the observation that SRS fish recently had measured mercury concentrations higher than those from off-site (Cummins et al. 1991, p. 141). The mosquitofish was selected as the sentinel species for this study. For this species, mercury was measured in whole fish after they were allowed to clear their guts overnight. Eleven SRS and 11 offsite locations were sampled during 1993. Median mercury concentrations ranged from approximately 0.00563 to $0.02416 \mathrm{ppm}$ wet weight for SRS samples and from 0.00563 to $0.02447 \mathrm{ppm}$ for offsite samples. (One offsite sample from the Savannah River and adjacent to Olin Mathieson Chemical Corporation did have very high concentrations of $0.2233 \mathrm{ppm}$ wet weight. These elevated concentrations were consistent with those measured in September 1990 at the same site (Heagler et al. 1993).) No significant difference in median mercury concentrations was detected between sites "on" or "off" SRS using nonparametric methods (Wilcoxon rank-sum test and $\alpha=0.05$ ). However, a significant difference ( $P=$ 0.02 ) was noted with this same test between sites influenced by Savannah River water (e.g., sites on the river or receiving river water for purposes such as cooling) and sites with no known influence of Savannah River water.

An investigation of the role of mercury in organisms from several aquatic systems at SRS and in the surrounding areas of Georgia and South Carolina was begun recently under an SREL genotoxicity program. These studies deal with physical genetic damage (DNA strand breaks) and its association with levels of mercury contamination in target organisms. To 
date, studies have concentrated on largemouth bass (Micropterus salmoides) from L Lake, Par Pond, Pond $B$, and Pond $C$ of SRS. The unpublished studies show a positive correlation between mercury contamination and genetic damage. Future studies will examine additional species from different trophic levels and additional sites. Controlled experiments are planned to examine the cause-and-effect relationships between DNA strand breaks and mercury.

\section{Par Pond Studies}

Clay et al. (1974) briefly surveyed Par Pond waterfowl for mercury concentrations and found that such concentrations tended to increase in waterfowl with an increase in percentage of diet consisting of animal matter. Results of muscle mercury concentrations for the five species studied are provided in Table 5-1; similar data for feather and liver mercury concentrations can be obtained from the original publication.

Table 5-1. Muscle Tissue Mercury Concentrations (ppm wet weight) for Five Waterfowl Species

Captured from Par Pond from October 1977 to March 1978 (Mean \pm standard error)

$\begin{array}{lll}\text { Species } & \begin{array}{l}\text { Number of } \\ \text { Birds }(n)\end{array} & \text { Concentration of } \\ \text { Hg (ppm wet weight) }\end{array}$

\begin{tabular}{lll} 
Horned Grebe (Podiceps auritus) & 7 & $2.38 \pm 0.08$ \\
Lesser Scaup (Aythya affinis) & 3 & $0.46 \pm 0.07$ \\
Bufflehead (Bucephala albeola) & 6 & $1.17 \pm 0.31$ \\
Ruddy Duck (Oxyura jamaicensis) & 3 & $0.33 \pm 0.09$ \\
American Coot (Fulica americana) & 30 & $0.09 \pm 0.02$ \\
\hline
\end{tabular}

Several studies have examined mercury bioaccumulation in Par Pond largemouth bass. In a 1977-1978 survey, Pinder and Giesy (1981a, b) measured concentrations of approximately $1.3 \mathrm{ppm}$ wet weight (converted from dry weight concentration provided in the original publication, assuming a correction factor of 0.25) in Par Pond bass. Pinder and Giesy (198la, b) used Par Pond bass to illustrate errors in interpreting metal bioaccumulation data if one has an inadequate knowledge of the data variance and covariance structure. They (Pinder and Giesy 1981a) demonstrated that correlations between elements accumulated in biota can arise from analytical sources (neutron activation, in this case) in addition to physiological processes. They (Pinder and Giesy 1981b) also demonstrated that interpretation of frequency distributions of elements among individuals in a population could not be linked to essentiality of an element. Continuing their study of Par Pond bass, Giesy and Pinder (unpublished manuscript) attempted to relate bass condition to mercury concentration. They noted that roughly 13 per cent of the captured bass were in very poor condition and referred to this as the "thin bass syndrome" in Par Pond. Par Pond bass condition ranged continuously from normal to emaciated. They found a negative correlation between bass muscle mercury concentration $(2.37 \pm 4.87 \mathrm{ppm}$ wet weight, $\mathrm{n}=48$ ) and bass condition. Longhi (1990) continued these studies of mercury bioaccumulation in Par Pond bass. Measured concentrations in bass muscle tissues ranged from approximately 0.2 to $2.5 \mathrm{ppm}$ wet weight in this survey; however, review of the associated primary data suggested that the accuracy of initial analyses was compromised for the Longhi study. Again, mercury in bass had a negative relationship with bass condition. Consistent with numerous other studies (e.g., Lange et al. 1993), bass mercury concentrations increased with bass size and age.

Jagoe (Jagoe et al. 1994) studied Par Pond bass mercury concentrations before and after the recent drawdown for dam repair. Concentrations measured from the fall of 1991 through the winter of 1993 ranged from 0.05 to $1.90 \mathrm{ppm}$ wet weight of bass muscle. They found a transient increase in mercury immediately after drawdown but there was no overall increase in mercury in Par Pond bass noted 1.5 years after drawdown. 


\section{Upper Three Runs Creek Studies}

Mercury in Upper Three Runs Creek was examined relative to the ETF discharge into this creek at Road C. Both water mercury concentrations and bioaccumulation were measured; however, initial analytical difficulties associated with water analyses lead to a primary focus on bioaccumulation in the dusky shiner (Notropis cummingsae). Bioaccumulation results were summarized in a July 30, 1992, letter from M. Newman (SREL) to W. Specht (SRTC). This letter is included as an appendix in Newman and Messier (1994).

Water mercury concentrations (unfiltered samples) were measured in Upper Three Runs Creek between April and September 1988. Briefly, samples were preserved in the field with the addition of bromine monochloride and placed on ice. Mercury from the sample was concentrated on gold, sputter-coated glass beads, then thermally driven into a nitrogen gas stream (Bloom and Crecelius 1983). The mercury in the gas was measured using a Coleman 50B cold-vapor atomic absorption spectrophotometer. The method detection limit was $1.8 \mathrm{ppt}$. The unpublished results generated before discontinuing water analyses are provided in Table 5-2.

Dusky shiner whole-body concentrations were measured before and after the ETF discharge began. An analysis of variance design was developed for the sampling. Three regions (above the ETF discharge point (Upper), at the discharge (Mid) and below the discharge (Lower) were sampled. Two sites were sampled per region and two schools of fish were sampled per site. Duplicate samples from each school were taken. Mean mercury concentrations ranged from 0.044 to $0.133 \mathrm{ppm}$ wet weight. Table 5-3 summarizes the results of this study. There was no significant difference in mercury bioaccumulation before and after ETF discharge began.

Table 5-2. Preliminary Mercury Analyses of Upper Three Runs Creek (U3R) Water. Concentrations are ppt. NS Indicates a Location was not Sampled on a Particular Date.

Sample Location

\begin{tabular}{llcl} 
4/6/88 & $4 / 20 / 88$ & $\begin{array}{c}\text { Sampling Date } \\
7 / 12 / 88\end{array}$ & $9 / 1 / 88$ \\
\hline 7.7 & 7.6 & .15 .2 & 3.2 \\
NS & 4.6 & $<1.8$ & NS \\
4.6 & 8.9 & 6.2 & 3.0 \\
NS & 2.4 & 14.3 & NS \\
NS & 6.0 & 12.5 & 3.5 \\
$<1.8$ & 2.1 & NS & $<1.8$ \\
\hline
\end{tabular}

Table 5-3. Mercury Concentrations (ppm wet weight) Measured in Dusky Shiners from Upper Three Runs Creek.

\begin{tabular}{llll} 
Date & $\begin{array}{l}\text { Region of } \\
\text { Watershed }\end{array}$ & Mercury (ppm) & $\begin{array}{l}\text { Number of fish pooled and } \\
\text { number of samples }\end{array}$ \\
\hline April 1987 & Upper & $0.125 \pm 0.024$ & 6 fish for all 8 samples \\
& Mid & $0.133 \pm 0.026$ & 6 fish for all 8 samples \\
October 1987 & Lower & $0.082 \pm 0.020$ & 6 fish for all 8 samples \\
& Upper & $0.094 \pm 0.126$ & 6 fish for all 8 samples \\
& Mid & $0.062 \pm 0.024$ & 6 fish for all 8 samples \\
October 1989 & Lower & $0.044 \pm 0.012$ & 6 fish for all 8 samples \\
& Upper & $0.125 \pm 0.040$ & 7 Individual fish samples \\
& Mid & $0.077 \pm 0.029$ & 7* Individual fish samples \\
October 1991 & Lower & $0.130 \pm 0.079$ & 8 Individual fish samples \\
& Upper & $0.058 \pm 0.011$ & 5 fish for 2 samples, \\
& Mid & $0.081 \pm 0.031$ & 6 for 6 samples \\
& Lower & $0.069 \pm 0.031$ & 6 fish for all 8 samples \\
& Fne abservation (one fish) was rejected as an outilier from this group of eight individual fish analyses. The Grubbs \\
single outlier test (one-tail with $\alpha=0.05$ ) was used for this purpose. &
\end{tabular}




\section{Basic Studies of Bioaccumulation}

SREL studies of mercury bioaccumulation began with an EPA-funded mesocosm project. A series of channel mesocosms was constructed in B Area and used to measure mercury fate in aquatic biota. In the first of two reports from this study (Kania and Beyers 1974), the influence on NTA (the trisodium salt of nitrilotriacetic acid) was found to modify mercury (added as $\mathrm{Hg}^{2+}$ ) bioaccumulation by mosquitofish. In the second report (Kania et al. 1976), more extensive examination of channel biota was described. Pairs of channels received 0.01, 1.0 and $5.0 \mathrm{ppb}$ of $\mathrm{Hg}^{2+}$ for almost a year. Mosquitofish placed into the channels had initial mercury concentrations of $0.04 \mathrm{ppm}$ wet weight but, after 10 months of exposure to $1 \mathrm{ppb}$ of $\mathrm{Hg}^{2+}$, had body concentrations in the range of 3.4 to $5.3 \mathrm{ppm}$ wet weight. After cessation of mercury input to the channels, mosquitofish quickly eliminated bioaccumulated mercury with an estimated biological half-life of 13.5 days. Sigmon et al. (1977) reported periphyton mercury concentrations as high as $\mathbf{3 0 0 0}$ ppm wet weight in the $1 \mathrm{ppb}$ channels. The dissertation of Kania (1981) contains further details regarding these studies.

Newman and Doubet (1989) also examined mercury (as $\mathrm{Hg}^{2+}$ ) bioaccumulation in the mosquitofish. They estimated size-dependent uptake and elimination constants for mosquitofish and contrasted the results with earlier studies (Newman and Mitz 1988) on zinc $(\mathrm{Zn})$ bioaccumulation kinetics. Uptake rates from water $(0.24 \mathrm{ppb})$ averaged $0.32 \mathrm{ppm}$ dry weight of fish/day. These rates increased as fish size decreased. Elimination rate constants averaged 0.14 day $^{-1}$ and were not significantly correlated with fish size. Both elimination rate and uptake rate constants were similar to those for $\mathrm{Hg}^{0}$ but larger than those for methylmercury. A subset of these data was used in three subsequent publications (Brisbin et al. 1990; Brisbin and Newman 1991; Matis et al. 1991) to develop alternative models of bioaccumulation.

\section{Basic Studies of Effects}

SREL studies of mercury effects also began with the channel mesocosm project (Kania and Beyers 1974; Kania et al. 1976; Kania 1981). A wide range of effects was examined, including modified predatorprey interactions, periphyton and macrobenthic invertebrate community responses. Kania and O'Hara (1974) measured impaired predator (largemouth bass) avoidance by mosquitofish exposed to sublethal . doses of mercury. In the channel mesocosms receiving mercury, periphyton colonization was retarded (Sigmon et al. 1977). Periphyton biomass increased with mercury treatment, but periphyton community diversity was lowered. The emergent plant, Juncus diffusissimus, was adversely affected by mercury. The channel insect community's diversity and evenness were depressed at the highest mercury concentrations.

Studies of mercury effects on mosquitofish continue at SREL. Newman, Mulvey, and coworkers have focused on population genetic and demographic markers of mercury effect. Significant effects of mosquitofish sex, size, and genotype at a glucosephosphate isomerase locus (PGI-2) were quantified during mercury or arsenic (As) exposure (Diamond et al. 1989; Newman et al. 1989; Heagler et al. 1993). Hidden population structure (Lee et al. 1992) and the source population (Diamond et al. 1991) also were demonstrated to have a significant influence on population response to mercury. A distinct metabolic shift was quantified in mercuryexposed mosquitofish (Kramer et al. 1992) and linked to the PGI-2 genotype effect mentioned above (Kramer et al. 1992; Kramer and Newman 1994). During chronic exposures to mercury, mosquitofish reproduction, but not growth, was affected (Mulvey et al. submitted). The effect on reproduction was different for the various PGI-2 genotypes. These differential PGI-2 genotype fitnesses and demographic shifts of mercury-exposed populations, are being assessed as markers of mosquitofish mercury exposure. 


\section{References}

Bloom, N.S., and E.A. Crecelius, 1983, "Determination of Mercury in Seawater at SubNanogram per Liter Levels," Mar. Chem. 14: 49-59.

Brisbin, I.L. Jr., M.C. Newman, S.G. McDowell and E.L. Peters, 1990, "Prediction of Contaminant Accumulation by Freeliving Organisms: Applications of a Sigmoidal Model," Environ. Toxicol. Chem. 9: 141-149.

Brisbin, I.L. Jr., and M.C. Newman, 1991, "Sigmoidal Models for the Uptake, Concentration and Effects of Metals in Consumer Organisms," Water, Air, and Soil Pollut. 57-58: 691-696.

Clay, D.L., I.L. Brisbin, Jr., P.B. Bush, and E.E. Provost, 1974, "Patterns of Mercury Contamination in a Wintering Waterfowl Community," Proc. Ann. Conf. S.E. Assoc. Fish \& Wildl. Agencies 32: 309317.

Cummins, C.L., D.K. Martin, and J.L. Todd, 1991, Savannah River Site Environmental Report for 1989, WSRC-IM-90-60. Westinghouse Savannah River Company, Savannah River Site, Aiken, SC.

Diamond, S.A., M.C. Newman, M. Mulvey, P.M. Dixon, and D. Martinson, 1989, "Allozyme Genotype and Time to Death of Mosquitofish, Gambusia affinis (Baird and Girard), During Acute Exposure to Inorganic Mercury," Environ. Toxicol. Chem. 8: 613622.

Diamond, S.A., M.C. Newman, M. Mulvey, and S.I. Guttman, 1991, "Allozyme Genotype and Time-toDeath of Mosquitofish, Gambusia holbrooki, During Acute Inorganic Mercury Exposure: A Comparison of Populations," Aquat. Toxicol. 21: 119-134.

Giesy, J.P. Jr. and J.E. Pinder, III., (unpublished manuscript), "Correlations Between Tissue Trace Element Concentrations and Body Condition of Largemouth Bass".

Heagler, M.G., M.C. Newman, M. Mulvey, and P.M. Dixon, 1993, "Allozyme Genotype in Mosquitofish, Gambusia holbrooki, During Mercury Exposure: Temporal Stability, Concentration Effects and Field Verification," Environ. Toxicol. Chem. 12: 385-395.

Jagoe, C., B. Grasman, and T. Youngblood, 1994, "Studies of the Effects of Drawdown of a Reservoir on Mercury Levels in Fish and Other Resident
Organisms," Abstract accepted for presentation at the Mercury as a Global Pollutant international conference, sponsored by EPRI in Whistler, BC, July 1994.

Kania, H.J., and J. O'Hara, 1974, "Behavioral Alterations in a Simple Predator-Prey System Due to Sublethal Exposure to Mercury," Trans. Amer. Fish. Soc. 103: 134-136.

Kania, H.J., and R.J. Beyers, 1974, "NTA and Mercury in Artificial Stream Systems," EPA-660/373-025, February 1974.

Kania, H.J., R.L. Knight, and R.J. Beyers, 1976, "Fate and Biological Effects of Mercury Introduced into Artificial Streams," EPA-600/3-76-060, August 1976.

Kania, H.J., 1981, "The Fate of Mercury Input into Artificial Stream Systems," Ph.D. Dissertation, University of Georgia.

Kramer, V.J., M.C. Newman, M. Mulvey, and G.R. Ultsch, 1992a, "Glycolysis and Krebs Cycle Metabolites in Mosquitofish, Gambusia holbrooki, Girard 1859, Exposed to Mercuric Chloride: Allozyme Genotype Effects," Environ. Toxicol. Chem 11: 357-364.

Kramer, V.J., M.C. Newman, and G.R. Ultsch, 1992b, "Changes in Concentrations of Glycolysis and Krebs Cycle Metabolites in Mosquitofish, Gambusia holbrooki, Induced by Mercuric Chloride and Starvation," Environ. Biol. Fishes 34: 315-320.

Kramer, V.J., and M.C. Newman, 1994, "Inhibition of Glucosephosphate Isomerase Alloymes of the Mosquitofish, Gambusia holbrooki, by Mercury," Environ. Toxicol. Chem. 13: 9-14.

Lange, T.R., H.E. Royals, and L.L. Connor, 1993, "Influence of Water Chemistry on Mercury Concentration in Largemouth Bass from Florida Lakes," Trans. Amer. Fish. Soc. 122: 74-84.

Lee, C.J., M.C. Newman, and M. Mulvey, 1992, "Time to Death of Mosquitofish (Gambusia holbrooki) During Acute Inorganic Mercury Exposure: Population Structure Effects," Arch. Environ. Contam. Toxicol. 22: 284-287. 
Longhi, M.P., 1990, "Mercury Retention in Largemouth Bass, Micropterus salmoides, from a South Carolina Reservoir," M.S. Thesis, Wake Forest University.

Matis, J.H., T.H. Miller, and D.M. Allen, 1991, "Stochastic Models of Bioaccumulation," M.C. Newman and A.W. McIntosh (eds.), Metal Ecotoxicology. Concepts and Applications, Lewis Publishers, Chelsea, MI.

Mulvey, M., M.C. Newman, A. Chazal, M.M. Keklak, M.G. Heagler, and L.S. Hales, Jr., (submitted), 'Demographic and Genetic Responses of Mosquitofish (Gambusia holbrooki Girard 1859) Populations Stressed by Mercury," Can. J. Fish: Aquat. Sci.

Newman, M.C., 1986, Water Quality. The Comprehensive Cooling Water Study Final Report. SREL-28.

Newman, M.C., S.A. Diamond, M. Mulvey, and P. Dixon, 1989, "Allozyme Genotype and Time to Death of Mosquitofish, Gambusia affinis (Baird and Girard), During Acute Toxicant Exposure: A Comparison of Arsenate and Inorganic Mercury", Aquat. Toxicol. 15: 141-156.
Newman, M.C., and D.K. Doubet, 1989, "SizeDependence of Mercury (II) Accumulation Kinetics in the Mosquitofish, Gambusia affinis (Baird and Girard)," Arch. Environ. Contam. Toxicol. 18: 819825.

Newman, M.C., and A. Messier, 1994, "Mercury Bioaccumulation in Mosquitofish (Gambusia holbrooki) Sampled on and Around the Savannah River Site," Report No. SREL-48, Savannah River - Ecology Laboratory, Aiken, SC.

Newman, M.C., and S.V. Mitz, 1988, "Size Dependence of Zinc Elimination and Uptake from Water by Mosquitofish, Gambusia affinis (Baird and Girard)," Aquatic Toxicol. 12: 17-32.

Pinder, J.E. III, and J.P. Giesy, 1981a, "Errors in Determining Elemental Concentrations and the Structure of Interelement Correlation Matrices," Ecology 62: 483-485.

Pinder, J.E. III, and J.P. Giesy, 1981b, "Frequency Distributions of the Concentrations of Essential and Nonessential Elements in Largemouth Bass, Micropterus salnwides," Ecology 62: 456-468.

Sigmon, C.F., H.J. Kania, and R.J. Beyers, 1977, "Reduction in Biomass and Diversity Resulting from Exposure to Mercury in Artificial Streams," J. Fish. Res. Board Can. 34: 493-500. 


\section{Chapter 6. Assessment of Intakes/Risk from SRS Mercury Releases}

Mercury in the environment originates from natural and anthropogenic sources. While natural sources release a significantly'larger amount of mercury annually, anthropogenic sources have been known to create concentrated deposits that can result in localized health effects.

The health effects of mercury are well known. Uncontrolled exposure can damage organs in the body, affect the central nervous system, and impact a developing fetus. The dose received and the form of the mercury determines onset and prognosis. Effects can occur from acute or chronic exposures, and the effects can be temporary or permanent. Typically, exposure occurs after breathing contaminated air, ingesting contaminated food, such as fish or water, or through contact with mercury compounds. Health effects from dermal exposure - except where mercury compounds designed for a topical application were overapplied or where skin contact was intense, as when a mercurial fungicide was applied to clothing - are less common.

Guidelines for calculating risk from chemicals can be found in the Risk Assessment Guidance for Superfund (EPA, 1989). Developed for. use in remedial investigationfeasibility studies at Superfund sites, the manual addresses the assessment of hazardous wastes and hazardous materials. Exposure pathways are assessed using models. Once the exposures are calculated, they are compared to reference doses listed in a summary table. The reference doses represent the estimated exposure levels for humans that are not likely to result in an appreciable risk of deleterious effects. 
This page intentionally left blank. 


\section{Assessment of the Impact of Mercury Releases at the SRS}

\section{Releases to Water}

No recent assessment of the risk from the mercury in the SWDF and seepage basins has been conducted. In 1976, Orebaugh and Hale mathematically modeled potential discharges from the Solid Waste Disposal Facility. Using $9,000 \mathrm{~kg}$ of mercury as the source term, Orebaugh and Hale concluded that a mercury flux of $-219 \mathrm{mg} / \mathrm{hr}$ may enter the water table and travel horizontally from the 643-E SWDF. As a worst case, this flux could contribute $\sim 0.0002 \mathrm{ppm}$ to Fourmile Branch using an average flow of $10^{6}$ liters per hour (Orebaugh and Hale 1976). This concentration is below the Drinking Water Standard of $0.002 \mathrm{ppm}$. A literature survey conducted in 1984 by Carden et al. did not identify any information that cast serious doubt on the conclusions reached by Orebaugh and Hale (Carden et al. 1984).

If an individual were to consume water directly from Fourmile Branch, the exposure from $0.0002 \mathrm{ppm}$ of mercury could be evaluated using a technique outlined in Risk Assessment Guidance for Superfund (EPA, 1989). Ingestion of mercury in drinking water was calculated using the following equation:

Intake $(\mathrm{mg} / \mathrm{kg}-\mathrm{d})=(\mathrm{CW} \times \mathrm{IR} \times \mathrm{EF} \times \mathrm{ED}) /(\mathrm{BW} \times \mathrm{AT})$

where:

$\mathrm{CW}$, chemical concentration in water $=0.0002 \mathrm{ppm}$

IR, ingestion rate $=0.67 \mathrm{l} / \mathrm{d}$ for $S R S$ workers and $2 \mathrm{~V} / \mathrm{d}$ for offsite individuals

$E F$, exposure frequency $=260 \mathrm{~d} / \mathrm{y}$ for SRS workers and $365 \mathrm{~d} / \mathrm{y}$ for offsite individuals

$E D$, exposure duration $=30 \mathrm{y}$ for SRS workers and $70 \mathrm{y}$ for offsite individuals

$\mathrm{BW}$, body weight $=70 \mathrm{~kg}$

AT, averaging time $=30$ y $\times 260 \mathrm{~d} / \mathrm{y}$ for SRS workers and 70 y $\times 365 \mathrm{~d} / \mathrm{y}$ for offsite individuals.

Assuming that a $70 \mathrm{~kg}$ SRS worker ingested 0.671 of water from Fourmile Branch daily for thirty years $(260 \mathrm{~d} / \mathrm{y})$, the exposure of $1.9 \times 10^{-6} \mathrm{mg} / \mathrm{kg}-\mathrm{d}$ would not exceed the EPA reference dose (oral) of $3 \times 10^{-4} \mathrm{mg} / \mathrm{kg}-\mathrm{d}$ for mercury. Similarly, assuming that an offsite $70 \mathrm{~kg}$ individual ingested $2 \mathrm{l}$ of water from Fourmile Branch for 70 years $(365 \mathrm{~d} / \mathrm{y})$, the exposure of $5.7 \times 10^{-6} \mathrm{mg} / \mathrm{kg}$-d would not exceed the EPA reference dose for mercury.

\section{Releases to Air}

While incomplete and based on years when production was not at its peak, the maximum 24-hour average concentration of mercury in air at the site boundary, as modeled for the years 1985-1990, was predicted to be $0.0024 \mu \mathrm{g} / \mathrm{m}^{3}$ (Hunter 1993). This concentration is well below the SCDHEC ambient standard of $0.25 \mu \mathrm{g} / \mathrm{m}^{3}$ of air. Modeling was conducted using the U.S. Environmental Protection Agency's Industrial Source Complex Short Term Model (ISCST), Release 2. The model represents a worst case, assuming continuous releases and discounting building effects that would enhance dispersion. A more recent estimate, associated with September 1993 information that included additional sources, predicted a maximum 24-hour average concentration of mercury at the site boundary of $0.014 \mu \mathrm{g} / \mathrm{m}^{3}$ - again, well below the ambient standard.

If an individual were to inhale the maximum predicted concentration of mercury at the site boundary, the exposure could be evaluated using a technique outlined in Risk Assessment Guidance for Superfund (EPA, 1989). Inhalation of airborne (vapor phase) chemicals was calculated using the following equation:

Intake $(\mathrm{mg} / \mathrm{kg}-\mathrm{d})=(\mathrm{CA} \times \mathrm{IR} \times \mathrm{ET} \times \mathrm{EF} \times \mathrm{ED})$ (BW $\times$ AT)

where:

$\mathrm{CA}$, contaminant concentration in air $=0.014 \mu \mathrm{g} / \mathrm{m}^{3}$

$\mathrm{IR}$, inhalation rate $=0.83 \mathrm{~m}^{3} / \mathrm{h}$

ET, exposure time $=8 \mathrm{~h} / \mathrm{d}$ for $S R S$ workers and $24 \mathrm{~h} / \mathrm{d}$ for offsite individuals

$E F$, exposure frequency $=260 \mathrm{~d} / \mathrm{y}$ for $S R S$ workers and $365 \mathrm{~d} / \mathrm{y}$ for offsite individuals

$E D$, exposure duration $=30 y$ for SRS workers and $70 \mathrm{y}$ for offsite individuals

$\mathrm{BW}$, body weight $=70 \mathrm{~kg}$ 
AT, averaging time $=30$ y $\times 260 \mathrm{~d} / \mathrm{y}$ for SRS workers and 70 y $\times 365 \mathrm{~d} / \mathrm{y}$ for offsite individuals

Assuming that a $70 \mathrm{~kg}$ SRS worker inhaled 0.014 $\mu \mathrm{g} / \mathrm{m}^{3}$ of mercury for 30 years $(260 \mathrm{~d} / \mathrm{y})$, the exposure of $1.3 \times 10^{-6} \mathrm{mg} / \mathrm{kg}-\mathrm{d}$ would not exceed the reference dose (inhalation) for mercury of $3 \times 10^{-3}$ $\mathrm{mg} / \mathrm{kg}$-day. Similarly, assuming that a $70 \mathrm{~kg}$ offsite individual inhaled $0.014 \mu \mathrm{g} / \mathrm{m}^{3}$ of mercury for 70 years ( $365 \mathrm{~d} / \mathrm{y})$, the exposure of $4 \times 10^{-6} \mathrm{mg} / \mathrm{kg}$-day would not exceed the reference dose for mercury.

\section{Total Risk from Oral and Inhalation Exposure}

The overall potential for effects from noncarcinogenic chemicals can be calculated assuming that the effects are additive. This is necessary if an individual can be the receptor for both source terms. While this exposure scenario is unlikely, it is a conservative estimate of the total risk.
The intake from each pathway is divided by its respective reference dose. The result is called the Noncancer Hazard Index or HI. The total risk from both oral and inhalation exposure requires that the HII from both pathways be summed. If the result exceeds unity, there may be concern for potential health effects. If the result does not exceed unity, there is no concern for potential health effects.

Assuming no other exposure, the total $\mathrm{HI}$ for a site worker was 0.01 while the total $\mathrm{HI}$ for an offsite individual was 0.03 . For both receptors, the total HI did not exceed unity, indicating that there is no concern for potential health effects.

\section{Summary}

Mercury has been detected in wells monitoring the groundwater beneath SRS, but not in water supply wells in excess of the Primary Drinking Water Limit of $0.002 \mathrm{ppm}$. There has been no significant release of mercury from SRS to the Savannah River. While releases to air are likely, based on process knowledge, modeling of the releases indicates concentrations that are well below the SCDHEC ambient standard. A significant effort will be required to fully model all the potential release points across the site and to develop a risk-based estimate of the potential health effects from buried mercury.

\section{References}

Carden, J.L., R. Kury, and G.G. Eichholz, 1984, Mercury Migration into Ground Water, A Literature Study Prepared for the Savannah River Laboratory, Topical Report - Project E26-602, CORR 84-00054, E.I. duPont de Nemours \& Co. Aiken, SC.

EPA, 1989, Risk Assessment guidance for Superfund, Volume I, Human Health Evaluation Manual (Part A), Interim Final, EPA/540/1-89/002, United States Environmental Protection Agency, December, 1989.
Hunter, C.H., 1993, Mercury, SRT-ETS-931137, Westinghouse Savannah River Company, Aiken, SC.

Orebaugh, E.G., and W.H. Hale, Jr., 1976, Dispersion Study of Buried Elemental Mercury, DP-1401, E.I. duPont de Nemours \& Co., Aiken, SC. 


\section{Appendix A}

\section{Environmental Monitoring for Mercury}

Mercury $(\mathrm{Hg})$ concentrations are monitored in liquid discharges from SRS, in onsite streams and the adjoining Savannah River, in sediment, and in fish. The analytical method used for mercury analyses is the cold-vapor atomic absorption method listed in "Standard Method for the Examination of Water and Wastewater" (Eighteenth edition, pg. 3-76). For sediment samples, the method used is the "Toxicity Characteristics Leaching Procedure" as described in 40 CFR Parts 261, 264, 271, and 301. This is followed by the cold-vapor atomic absorption analyses of the resulting extract for mercury. Fish tissue is dissolved using a nitric acid/sulfuric acid mixture, and the resulting liquid is analyzed using the cold-vapor atomic absorption method. The data generated are reported either in the annual SRS Environmental Report or in the form of a discharge monitoring report to the South Carolina Department of Health and Environmental Control (SCDHEC). 
This page intentionally left blank. 


\section{Mercury In Water Discharges}

Water discharges are regulated by the U.S. Environmental Protection Agency (EPA) and SCDHEC with National Pollutant Discharge Elimination System (NPDES) permits. These permits require that water discharges from SRS be tested for specific parameters, based on the process from which the water originates. The site has three NPDES Permits; SC0000175, SC0044903, and the General Stormwater Permit SCR00000. At 13 NPDES permitted discharge points, the site is required to test the water for mercury. These discharge points are listed below.

\section{NPDES Sampling Locations and Frequency of Sampling for Mercury}

$\begin{array}{ll}\text { F-008 (F-Area) } & \text { 4/year } \\ \text { F-012 (F-Area) } & \text { 1/discharge } \\ \text { F-013 (F-Area) } & \text { 1/discharge } \\ \text { H-012 (H-Area) } & \text { 4/year } \\ \text { H-016 (H-Area) } & \text { 1/week } \\ \text { H-017 (H-Area) } & \text { 1/discharge } \\ \text { H-018 (H-Area) } & \text { 1/discharge } \\ \text { SC-004 (Steel Creek) } & \text { 1/month } \\ \text { X-014 (TNX) } & \text { 1/week }\end{array}$

\section{NPDES Stormwater Discharge Locations and Frequency of Sampling}

$\begin{array}{ll}\text { E-001 (Burial Ground) } & \text { 2/year } \\ \text { GS-002 (SATA) } & \text { 2/year } \\ \text { S-005 (S-Area) } & \text { 2/year } \\ \text { X-001 (TNX) } & \text { 2/year }\end{array}$

\section{Surface Water Surveillance for Mercury}

Because mercury is a possible constituent of the surface water discharges regulated by the NPDES permits and a possible contaminant from discharges to the Savannah River upstream of SRS, it is included in the site ambient-water monitoring or surveillance program. This program consists of three river locations and eight site stream locations, which are sampled monthly. Two control locations test surface water for mercury levels upstream of the site (Upper Three Runs-1A and Savannah River-2 at River Mile 160). These stations give an indication of environmental levels of mercury before site contributions. Eight site streams and one river location are checked for mercury after SRS contributions. The Savannah River is checked for mercury immediately downstream of the Plant Vogtle discharge. These points and the control river and stream sites are listed below.

\section{Savannah River Sampling Locations (Sampled Monthly)}

River Mile 160 (River 2)

Plant Vogtle discharge

River Mile 120 (River 10)

\section{Site Stream Sampling Locations (Sampled Monthly)}

Tims Branch (TB-5) @ Road C Upper Three Runs (U3R-1A @ Road 8-1)

Upper Three Runs (U3R-4 @ Road A)

Fourmile Branch (FMC @ Road A-7)

Fourmile Branch (FMC-6 @ Road A-13.2)

Pen Branch (PB-3 @ Road A) .

Steel Creek (SC-4 @ ROAD A)

Lower Three Runs (L3R-2 @ Patterson Mill Road) 


\section{Sediment Sampling for Mercury}

Stream sediments are a known repository for heavy metals; therefore, a sampling and analysis program for metals, including mercury in sediments, is in place at SRS. This program checks for mercury at three river locations, one of which is a control, and at eight site stream locations, two of which are controls. The sites and the sampling frequency are listed below.

\section{Savannah River Locations (Sampled Annually)}

River Mile 160 (River 2)

Plant Vogtle discharge

River Mile 120 (River 10)

\section{Site Stream Locations (Sampled Annually)}

\author{
Upper Three Runs (U3R-4 at Road A) \\ Beaver Dam Creek (BDC at 400 D) \\ Fourmile Branch (FMC-6 at Road A-13.2) \\ Pen Branch (PB-3 at Road A) \\ Steel Creek (SC-4 at ROAD A) \\ Lower Three Runs (L3R-2 at Patterson Mill Road)
}

\section{Control Sites (Sampled Annually)}

Upper Three Runs (U3R-4 @ Road A)

Tinker Creek at Kennedy Pond Road

\section{Mercury In Fish}

Organisms in the ecosystem tend to concentrate contaminants in higher level predators as the contaminants move up the food chain. Therefore, fish, which are consumed by-humans, are tested for mercury contamination. These fish are collected by rod and reel, hoop nets, and electroshocking. A tissue sample is taken, dissolved in a nitric/sulfuric acid mixture, and analyzed in the same manner as the water samples. Eight Savannah River locations, nine site locations and two Edisto River locations are sampled annually for three types of fish. Five bass, five bluegill, and five catfish all weighing in excess of 50 grams are collected at each site. A list of sites is given below.

\section{Savannah River Locations}

Savannah River downstream of Augusta Lock and Dam (upstream of SRS)

Upper Three Runs Creek Mouth

Fourmile Branch Mouth

Steel Creek Mouth

Lower Three Runs Creek Mouth

US Highway 301 Bridge Area

Stokes Bluff Landing

US Highway 17A Bridge Area

\section{Site Stream Locations}

Upper Three Runs (U3R-4 at Road A)

Beaver Dam Creek (BDC at 400 D)

Fourmile Branch (FMC-6 at Road A-13.2)

Pen Branch (PB-3 at Road A-13.2)

L-Lake

Steel Creek (SC-4 at Road A)

Pond B

Par Pond

Lower Three Runs (L3R-2 at Patterson Mill Road.)

\section{Edisto River Control Sites}

West Bank Landing

Live Oak Landing 




\section{SAVANNAH RIVER SITE}

\section{U.S. Department of Energy/Savannah River Field Office}

S.R. Wright (60)

703-47A

\section{Westinghouse Savannah River Company}

$\begin{array}{ll}\text { R.P. Addis } & \text { 773-A } \\ \text { D.M. Beals } & 735-\mathrm{A} \\ \text { R.W. Benjamin } & 773-41 \mathrm{~A} \\ \text { J.P. Bibler } & 773-\mathrm{A} \\ \text { B.C. Blunt } & 742-\mathrm{A} \\ \text { A.L. Boni } & 773-\mathrm{A} \\ \text { J.A. Bowers } & 773-42 \mathrm{~A} \\ \text { R.R. Campbell } & 703-\mathrm{A} \\ \text { T.L. Capeletti } & 773-\mathrm{A} \\ \text { W.H. Carlton (80) } & 773-\mathrm{A} \\ \text { G.. Clare } & 703-31 \mathrm{~A} \\ \text { C.E. Coffey } & 773-\mathrm{A} \\ \text { J.W. Cook } & 742-\mathrm{A} \\ \text { J.C. Corey } & 773-\mathrm{A} \\ \text { C.L. Cummins } & 773-42 \mathrm{~A} \\ \text { L.B. Curtis } & 703-\mathrm{A} \\ \text { M. Denham } & 773-42 \mathrm{~A} \\ \text { P.W. Dickson } & 703-\mathrm{A} \\ \text { M.A. Ebra } & 773-\mathrm{A} \\ \text { O.M. Ebra-Lima } & 773-\mathrm{A} \\ \text { L. Eldridge } & 735-11 \mathrm{~A} \\ \text { W.A. Emel } & 735-\mathrm{A} \\ \text { J.B. Gladden } & 773-42 \mathrm{~A} \\ \text { D.E. Gordon } & 742-\mathrm{A} \\ \text { J.E. Halverson } & 735-\mathrm{A} \\ \text { D.W. Hayes } & 735-\mathrm{A} \\ \text { J.S. Haselow } & 773-42 \mathrm{~A} \\ \text { L.A. Haselow } & 992-4 \mathrm{~W} \\ \text { J.D. Heffner } & 735-16 \mathrm{~A} \\ \text { M.J. Hitchler } & 773-\mathrm{A} \\ \text { H.P. Holcomb } & 992-4 \mathrm{~W}\end{array}$

E.W. Holtzscheiter

T. Jannik

N.D. Johnson

J.F. Jordan

M.V. Kantelo

E.J. Kvartek

R. Lorenz

W.S. Loring

D.K. Martin

W.R. McDonell

N. Mims, Jr.

D.B. Moore-Shadrow

C.E. Murphy, Jr.

L.M. Papouchado

J.B. Pickett

D.J. Ratchford

J.S. Roberts

H.J. Stafford

C.R. Sherman

A.A. Simpkins

D.E. Stephenson

W.E. Stevens

D.A. Stevenson

R.N. Strom

L.L. Thebo

L.L. Tovo

D.M. Tuck

G.G. Tunno

E.L. Wilhite

W.G. Winn

S. Wood

SRTC Records (2)

\section{Savannah River Ecology Laboratory}

773-A

735-11A

735-A

703-A

735-A

773-61A

735-16A

735-A

992-4W

773-41A

735-A

773-A

$773-42 A$

773-A

730-M

703-F

742-A

735-15A

742-A

773-A

992-4W

773-42A

CCC-1

773-42A

992W-2

773-A

676-14T

735-A

773-A

735-A

773-A

773-A
D.C. Adriano

P. Bertsch

S.B. Clark

T. Hinton

M.C. Newman
737-A

737-A

737-A

737-A

737-A
J.E. Pinder

M.H. Smith

C.L. Strojan

F.W. Whicker
737-A

737-A

737-A

737-A

\section{EXTERNAL}

Environmental Advisory Committee, c/o C.E. Murphy, Jr, 773-42A (6)

J.E. Till, Neeses, SC 
